\title{
Shift in Kiss1 Cell Activity Requires Estrogen Receptor $\alpha$
}

\author{
Renata Frazão, ${ }^{1}$ Roberta M. Cravo, ${ }^{1}$ Jose Donato Jr, ${ }^{1}$ Dhirender V. Ratra, ${ }^{1}$ Deborah J. Clegg, ${ }^{2}$ Joel K. Elmquist, ${ }^{1,3}$ \\ Jeffrey M. Zigman, ${ }^{1}$ Kevin W. Williams, ${ }^{1 \star}$ and Carol F. Elias ${ }^{1 \star}$ \\ ${ }^{1}$ Division of Hypothalamic Research, Department of Internal Medicine, ${ }^{2}$ Touchstone Diabetes Center, Department of Internal Medicine, and ${ }^{3}$ Department \\ of Pharmacology, University of Texas Southwestern Medical Center, Dallas, Texas 75390
}

Reproductive function requires timely secretion of gonadotropin-releasing hormone, which is controlled by a complex excitatory/ inhibitory network influenced by sex steroids. Kiss1 neurons are fundamental players in this network, but it is currently unclear whether different conditions of circulating sex steroids directly alter Kiss 1 neuronal activity. Here, we show that Kiss1 neurons in the anteroventral periventricular and anterior periventricular nuclei $(\mathrm{AVPV} / \mathrm{PeN})$ of males and females exhibit a bimodal resting membrane potential (RMP) influenced by $\mathrm{K}_{\mathrm{ATP}}$ channels, suggesting the presence of two neuronal populations defined as type I (irregular firing patterns) and type II (quiescent). Kiss1 neurons in the arcuate nucleus (Arc) are also composed of firing and quiescent cells, but unlike AVPV/PeN neurons, the range of RMPs did not follow a bimodal distribution. Moreover, Kiss1 neuronal activity in the AVPV/PeN, but not in the Arc, is sexually dimorphic. In females, estradiol shifts the firing pattern of AVPV/PeN Kiss1 neurons and alters cell capacitance and spontaneous IPSCs amplitude of AVPV/PeN and Arc Kiss1 populations in an opposite manner. Notably, mice with selective deletion of estrogen receptor $\alpha(\mathrm{ER} \alpha)$ from Kiss1 neurons show cellular activity similar to that observed in ovariectomized females, suggesting that estradiolinduced changes in Kiss1 cellular properties require $\mathrm{ER} \alpha$. We also show that female prepubertal Kiss1 neurons are under higher inhibitory influence and all recorded AVPV/PeN Kiss1 neurons were spontaneously active. Collectively, our findings indicate that changes in cellular activity may underlie Kiss1 action in pubertal initiation and female reproduction.

\section{Introduction}

Pubertal development and reproductive function require the timely secretion of gonadotropin-releasing hormone (GnRH). $\mathrm{GnRH}$ neurons are active during embryonic development and early postnatal life until reaching a relatively quiescent state referred to as the "juvenile pause" (Styne, 1994; Plant and BarkerGibb, 2004; Sisk and Foster, 2004). Puberty is initiated with the increased activity of GnRH neurons and resultant higher pulsatile frequency of GnRH secretion. The factors involved in $\mathrm{GnRH}$ reawakening remain unclear, but evidence suggests that during the pubertal transition, a complex network of inhibitory and excitatory inputs alters GnRH neuronal activity and morphology (Brann and Mahesh, 1994; Sisk and Foster, 2004; Ojeda et al., 2006; Cookson et al., 2012). These changes induce coordinated

Received April 2, 2012; revised Dec. 3, 2012; accepted Dec. 4, 2012.

Author contributions: K.W.W. and C.F.E. designed research; R.F., R.M.C., J.D.J., and D.R. performed research;D.C., J.K.E., and J.M.Z. contributed unpublished reagents/analytic tools; R.F. analyzed data; R.F., K.W.W., and C.F.E. wrote the paper.

This work was supported by the NIH grants (R01HD061539, R01HD69702 to C.F.E.; K01DK087780 to K.W.W. K08DK068069 and R01DA024680 to J.M.Z.; R01DK53301, RL1DK081185, and by support from the American Diabetes association to J.K.E.; R01DK073689 to D.J.C.) and by the National Council for Scientific and Technological Development (CNPq-Brazil) 201804/2008-5 (to R.F.). Hormone assays were performed by The University of Virginia Center for Research in Reproduction Ligand Assay and Analysis Core, supported by the Eunice Shriver NICHD/NIH (SCCPIR) (U54-HD28934). We thank Dr. Jong-Woo Sohn and Dr. Suzanne Moenter for helpful discussions.

*K.W.W. and C.F.E. are joint senior authors.

Correspondence should be addressed to either Dr. Kevin W. Williams, Department of Internal Medicine, University of Texas Southwestern Medical Center, 5323 Harry Hines Boulevard, Y6-214B Dallas, TX 75390-9077, E-mail: kevin.williams@utsouthwestern.edu; or Dr. Renata Frazão at her present address: Department of Anatomy, Institute of Biomedical Sciences, University of São Paulo, Avenue Prof. Lineu Prestes 2415, room 108, São Paulo 05508-900, Brazil. E-mail: rfrazao@usp.br.

DOI:10.1523/JNEUROSCI.1610-12.2013

Copyright $\odot 2013$ the authors $\quad 0270-6474 / 13 / 332807-14 \$ 15.00 / 0$ secretion of gonadotropins, which, in females, culminates in the first estrus and cyclicity (Apter et al., 1993; Wu et al., 1996; Plant, 2001). Gonadotropins stimulate synthesis and secretion of gonadal steroids, creating an estrogen-mediated negative feedback loop that results in the inhibition of GnRH release. Rising levels of estrogen in the afternoon of the proestrus day generate a positive feedback loop, required for the LH surge and ovulation (Levine and Ramirez, 1982; Levine et al., 1982; Moenter et al., 1992b, 2009; Herbison and Pape, 2001; Herbison et al., 2008). The effects of estrogen are mediated by interneurons that impinge on GnRH neurons modulating cell activity and patterns of GnRH release (Petersen et al., 2003; Wintermantel et al., 2006; Christian and Moenter, 2007).

The neuropeptide kisspeptin plays a fundamental role in this complex network. Inactivating mutations of the KISS1/Kiss1 gene or of kisspeptin receptor (GPR54/Gpr54) gene cause lack of sexual maturation and infertility (Funes et al., 2003; Seminara et al., 2003; de Roux et al., 2003; Lapatto et al., 2007; d'Anglemont de Tassigny et al., 2007; Topaloglu et al., 2012). Expression of GPR54/Gpr54 and KISS1/Kiss1 genes increases across pubertal transition and exogenous administration of kisspeptin advances the onset of puberty (Navarro et al., 2004; Han et al., 2005; Shahab et al., 2005). Moreover, GnRH neurons express Gpr54 mRNA, and kisspeptin is a potent activator of $\mathrm{GnRH}$ cell activity and secretion (Irwig et al., 2004; Han et al., 2005; PieleckaFortuna et al., 2008).

Estrogen differentially modulates Kiss 1 gene expression in the preoptic area and the arcuate nucleus (Smith et al., 2005b, 2007; Gottsch et al., 2009). These effects are mediated by estrogen receptor $\alpha(\mathrm{ER} \alpha)$ as estrogen-induced changes in Kiss 1 mRNA are 
disrupted in ER $\alpha$ knock-out mice (Smith et al., 2005a). Selective deletion of ER $\alpha$ from Kiss1 neurons advanced the onset of puberty, suggesting that estrogen signaling in Kiss1 neurons mediates a "pubertal brake" in which the removal of estrogen signaling disinhibits GnRH neurons (Mayer et al., 2010).

These studies have highlighted a role for Kiss1 neurons as gatekeepers of $\mathrm{GnRH}$ secretion during the onset of puberty and in the feedback actions of estrogen. However, it is unknown whether the action of kisspeptin is the result of direct changes in Kiss1 cellular activity. In the current study, we used patch-clamp recordings to test the hypothesis that different conditions of circulating sex steroids alter the biophysical and morphological properties of Kiss 1 neurons, which may underlie the role of kisspeptin in pubertal initiation and estrogen feedback actions on GnRH secretion.

\section{Materials and Methods}

Subjects. Female (8-10 weeks old) and male Kiss1-Cre/GFP ( $n=15$, $8-10$ weeks old) mice expressing enhanced green fluorescent protein (eGFP) under the transcriptional control of Cre-recombinase were used (Cravo et al., 2011). Kiss1-Cre/GFP females were divided into four groups: diestrus (estrous cycle monitored by vaginal cytology, $n=26$ ), ovariectomized (OVX, 7-10 d before cell recordings, $n=13$ ), ovariectomized and simultaneously implanted with a SILASTIC capsule (DowCorning) containing $1.0 \mu \mathrm{g}$ of $17 \beta$-estradiol (Sigma) suspended in sesame oil (OVX $+\mathrm{E} 2,3-4 \mathrm{~d}$ before cell recordings, $n=6)$, and prepubertal ( $18-25 \mathrm{~d}$ old, showing no vaginal opening, $n=4)$. In addition, Kiss1-Cre/GFP mice were crossed with ER $\alpha^{\text {flox/flox }}$ mice (Feng et al., 2007; $\mathrm{Xu}$ et al., 2011) to selectively delete $\mathrm{ER} \alpha$ from Kiss1 neurons; and Kiss 1 neurons from intact ( $n=4)$ and $\operatorname{OVX}(n=3,7-10 \mathrm{~d}$ prior recordings) postpubertal 35-day old Kiss1-Cre/GFP/ER $\alpha^{\text {flox/flox }}$ mice were recorded. All mice used in this study were housed in the University of Texas Southwestern Medical Center Animal Resource Center, in a light $(12 \mathrm{~h} \mathrm{on} / 12 \mathrm{~h}$ off) and temperature $\left(21-23^{\circ} \mathrm{C}\right)$ controlled environment. They were fed standard chow diet (Harlan Teklad Global Diet, Harlan Laboratories) and had ad libitum access to water. All experiments were carried out in accordance with the guidelines established by the National Institute of Health Guide for the Care and Use of Laboratory Animals, as well as with those established by the University of Texas Institutional Animal Care and Use Committee.

Whole-cell recording. Whole-cell patch-clamp recordings were performed in Kiss 1 neurons expressed in the anteroventral periventricular and anterior periventricular nuclei (AVPV/PeN) and the arcuate nucleus (Arc). During the recordings, neurons were maintained in hypothalamic slice preparations and data analyses were performed as previously described (Hill et al., 2008; Williams et al., 2010). Before perfusion, blood samples were collected directly from the heart. Hormone assays were performed by The University of Virginia Center for Research in Reproduction Ligand Assay and Analysis Core. Mice were decapitated and the entire brain was removed. After removal, brains were immediately submerged in ice-cold, carbogen-saturated $\left(95 \% \mathrm{O}_{2}\right.$ and $\left.5 \% \mathrm{CO}_{2}\right)$ ACSF (126 mM NaCl, $2.8 \mathrm{~mm} \mathrm{KCl}, 1.2 \mathrm{~mm} \mathrm{MgCl} 2,2.5 \mathrm{~mm} \mathrm{CaCl} 2,1.25 \mathrm{~mm}$ $\mathrm{NaH}_{2} \mathrm{PO}_{4}, 26 \mathrm{~mm} \mathrm{NaHCO}$, and $5 \mathrm{~mm}$ glucose). Coronal sections from a hypothalamic block $(250 \mu \mathrm{M})$ were cut with a Leica VT1000S Vibratome and then incubated in oxygenated ACSF at room temperature for at least $1 \mathrm{~h}$ before recording. Slices were transferred to the recording chamber and allowed to equilibrate for $10-20 \mathrm{~min}$ before recording. The slices were bathed in oxygenated $\operatorname{ACSF}\left(32^{\circ} \mathrm{C}-34^{\circ} \mathrm{C}\right)$ at a flow rate of $\cong 2$ $\mathrm{ml} / \mathrm{min}$. The pipette solution for whole-cell recording was modified to include an intracellular dye (Alexa Fluor 594) for whole-cell recording: $120 \mathrm{~mm}$ K-gluconate, $10 \mathrm{~mm} \mathrm{KCl,} 10 \mathrm{~mm}$ HEPES, 5 mm EGTA, $1 \mathrm{~mm}$ $\mathrm{CaCl} 2,1 \mathrm{~mm} \mathrm{MgCl} 2,2 \mathrm{~mm}$ (Mg)-ATP, and $0.03 \mathrm{~mm}$ Alexa Fluor 594 hydrazide dye, $\mathrm{pH}$ 7.3. Most of the experiments assessing the resting membrane potential and spontaneous action potentials were obtained in the absence of glutamatergic and GABAergic antagonists. Epifluorescence was briefly used to target fluorescent cells, at which time the light source was switched to infrared differential interference contrast imaging to obtain the whole-cell recording (Nikon Eclipse FN1 equipped with a fixed stage and a QuantEM:512SC electron-multiplying charge-coupled device camera). Electrophysiological signals were recorded using an Axopatch 700B amplifier (Molecular Devices), low-pass filtered at $2-5 \mathrm{kHz}$, digitized at $88 \mathrm{kHz}$ (Neuro-corder; Cygnus Technology), and analyzed offline on a PC with pCLAMP programs (Molecular Devices) or Minianalysis (Synaptosoft). Recording electrodes had resistances of 2.5-5 $\mathrm{M} \Omega$ when filled with the K-gluconate internal solution. Input resistance was assessed by measuring voltage deflection at the end of the response to a hyperpolarizing rectangular current pulse ( $500 \mathrm{~ms}$ of -10 to $-50 \mathrm{pA})$. For some experiments measuring voltage, the K-gluconate was replaced by equimolar Cs-gluconate. Membrane potential values were compensated to account for junction potential $(-8 \mathrm{mV})$. After characterizing membrane potential, neurons were tested in voltage-clamp mode with a holding potential of $-50 \mathrm{mV}$. CNQX (10 $\mu \mathrm{M})$, AP5 (50 $\mu \mathrm{M})$ and picrotoxin $(50-100 \mu \mathrm{M})$ were added to the ACSF for 5-10 min. Solutions containing estradiol were typically perfused for $15 \mathrm{~min}$.

Drugs. Estradiol, picrotoxin, CNQX, AP-5, and tolbutamide were obtained from Sigma. TTX and diazoxide were obtained from Tocris Bioscience. All solutions were made according to manufacturer's specifications. Stock solutions of diazoxide were made by dissolution in DMSO (Sigma). The concentration of DMSO in the external solution was $<0.1 \%$.

Immunohistochemistry. To assess Kiss1 neuron morphology, Kiss1Cre/GFP female mice were perfused with $10 \%$ buffered formalin and hypothalamic sections were processed for GFP immunohistochemistry, as previously described (Cravo et al., 2011). Sections were coverslipped with mounting medium containing the nuclear dye 4,6-diamino-2phenylindole dihydrochloride (DAPI, Vector Laboratories). The putative Kiss1 neurons (Kiss1/Cre-GFP) from OVX and OVX+E2 mice in which the nucleus was evident were selected for area measurement using Axion vision software (Zeiss). Numbers of Kiss1 neurons were determined by quantification of total number of neurons expressing GFP immunoreactivity (20× magnification) in two levels and one side of the AVPV and of the Arc from females on diestrus and Kiss1-Cre/GFP/ $\mathrm{ER} \alpha^{\text {flox/flox }}$ female mice.

In situ hybridization. To assess Kiss 1 and Slc17a6 (vGluT2) gene expression in OVX, OVX+E2, and Kiss1-Cre/GFP/ER $\alpha^{\text {flox/flox }}$ mice, singlelabel in situ hybridization histochemistry was performed in one series of hypothalamic sections ( $n=3$ /group). Brain sections were mounted onto SuperFrost plus slides (Fisher Scientific), pretreated in $0.1 \mathrm{M}$ citric acid, $\mathrm{pH} 6.0$, under microwave for $10 \mathrm{~min}$ and hybridized using ${ }^{35} \mathrm{~S}$ - or ${ }^{33} \mathrm{P}$ labeled riboprobes, as described previously (Zigman et al., 2006; Scott et al., 2009; Cravo et al., 2011).

Statistical analyses. Statistical data are expressed as mean \pm SEM, where $n$ represents number of cells. Tests to assess possible differences in variances were performed in all comparisons. Comparison between two groups was carried out using the unpaired two-tailed Student's $t$ test. One-way ANOVA followed by the pairwise Tukey test were used to compare three or more groups simultaneously. Non-parametric (MannWhitney or Kruskal-Wallis) tests were applied in comparisons that did not show equal variances. Statistical analysis was performed using GraphPad Prism software. $p$ value of 0.05 was considered significant in all analyses. Degrees of freedom (DF) for $t$ statistics are marked as $t={ }_{(\mathrm{DF})}$.

\section{Results \\ AVPV Kiss1 neurons in male and female mice exhibit heterogeneous biophysical properties}

To identify Kiss1 neurons in the preoptic area (AVPV and PeN) and in the arcuate nucleus (Arc), mice that express Crerecombinase via Kiss1 regulatory elements (Cravo et al., 2011) were crossed to reporter mice that express eGFP under R26-GFP

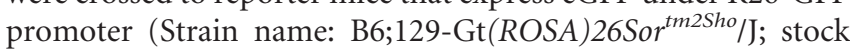
number: 004077). Cre-activity results in the irreversible excision of the DNA segment between two loxP sites (Gaveriaux-Ruff and Kieffer, 2007), resulting in GFP fluorescence that can be used to identify Kiss1-expressing neurons in varying physiological conditions and across development. Kiss1-Cre/GFP neurons in the 


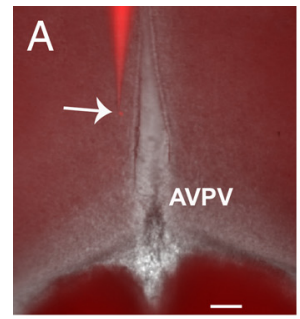

F

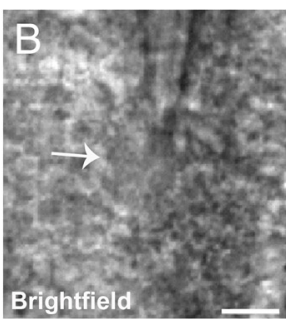

Brightfield

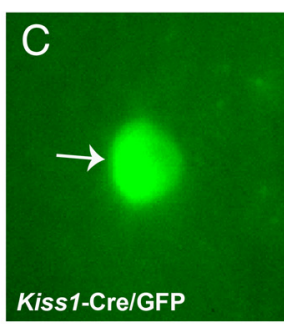

G
AVPV (Female)
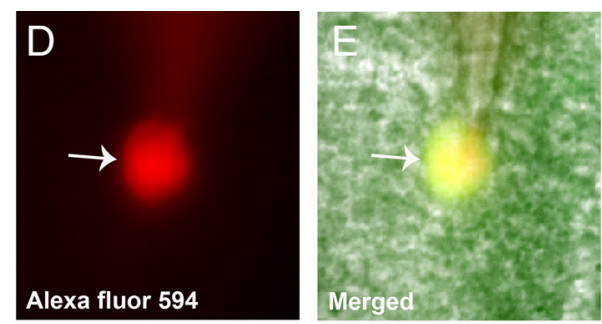

AVPV (Female)

Type I (Firing)

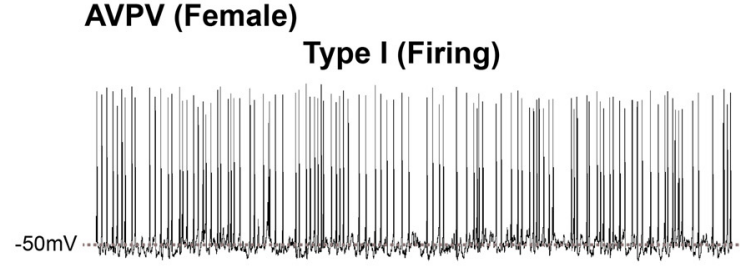

$\mathrm{H}$ AVPV (Male)

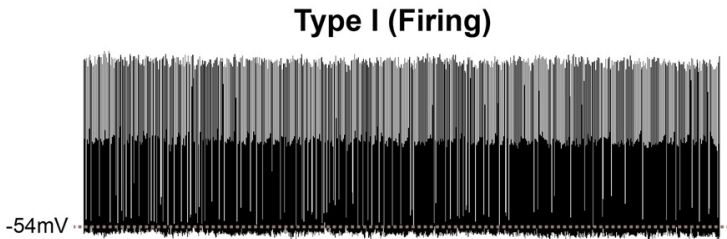

$J$

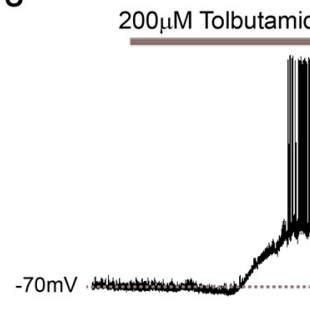

Type II (Quiescent)

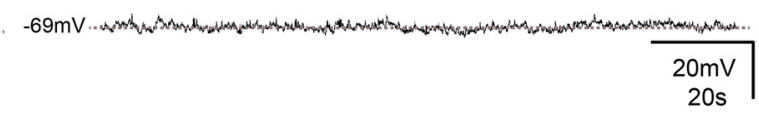

I

AVPV (Male)

Type II (Quiescent)

Figure 1. Kiss1 neurons in the AVPV exhibit irregular and quiescent firing patterns. $\boldsymbol{A}-\boldsymbol{E}$, Identification of Kiss1-Cre/GFP cells for whole-cell patch-clamp recordings. $\boldsymbol{A}-\boldsymbol{E}$, Low magnification for anatomical reference $(\boldsymbol{A})$; brightfield illumination showing a targeted neuron $(\boldsymbol{B})$; the same neuron under fluorescent (FITC) illumination $(\boldsymbol{C})$; complete dialysis of AlexaFluor 594 from the intracellular pipette at the end of the recording (D); colocalization of Alexa Fluor 594 and GFP (E). $\boldsymbol{F}$-G, Type I and type II AVPV/PeN Kiss 1 neurons in current-clamp mode. Dashed lines indicate the RMP. H-I, Type I AVPV/PeN Kiss1 neurons of males exhibited higher frequency of action potential ( fAPs) compared with females. J, Current-clamp recording demonstrates that tolbutamide $(200 \mu \mathrm{m})$ depolarizes Kiss 1 neurons of the preoptic area (AVPV/PeN). $\boldsymbol{K}$, Current-voltage relationships were examined in the same cell in $\boldsymbol{J}$, before (control) and after application of tolbutamide, by applying voltage ramps $(-120$ to $50 \mathrm{mV}$ in $1 \mathrm{~s}, 100 \mathrm{mV} / \mathrm{s})$. The tolbutamide-induced inward current had a reversal potential of $-90 \mathrm{mV}$, which is close to the predicted $\mathrm{E}_{\mathrm{K}}{ }^{+}$. Scale bars: $\boldsymbol{A}, 100 \mu \mathrm{m} ; \boldsymbol{B}-\boldsymbol{E}, 10 \mu \mathrm{m}$.

preoptic area and in the Arc were targeted using epifluorescence and Nomarski (i.e., IR-DIC) illumination (Fig. $1 A, B$ ). Kiss1-Cre neurons were identified by eGFP signal under a fluorescent microscope (Fig. 1C). AlexaFluor 594 hydrazide was added to the intracellular pipette solution for real-time confirmation that eGFP-positive neurons were targeted for recording (Fig. $1 D, E$ ) and for post hoc identification of the neuroanatomical distribution of the recorded cells. To monitor membrane potential and neuronal excitability, whole-cell recordings were performed in Kiss1-Cre/GFP neurons confined to the AVPV, PeN, and Arc in females (in diestrus) and males. Importantly, all biophysical properties examined were statistically similar between populations of AVPV and PeN Kiss1 neurons (data not shown). Thus, unless otherwise indicated, the data from AVPV and PeN Kiss1 neurons will be reported together (AVPV/PeN) for the remainder of this manuscript.
In current-clamp mode, Kiss1-Cre/GFP neurons were recorded under zero current injection $(\mathrm{I}=0)$ in whole-cell patchclamp configuration. The average resting membrane potential (RMP) of all AVPV/PeN Kiss1 neurons recorded from females in diestrus was $62.2 \pm 1.8 \mathrm{mV}$ (range $-43 \mathrm{mV}$ to $-81 \mathrm{mV}, n=38$ cells from 20 mice). Notably, we observed two populations of AVPV/PeN Kiss1 neurons from female mice as defined by cellular activity. Type I AVPV/PeN Kiss1 neurons exhibited overshooting action potentials (APs) with an irregular firing pattern ( $30 \%$ of total recorded cells; $1.9 \pm 0.3 \mathrm{~Hz}, n=11$ ), while type II AVPV/PeN Kiss1 neurons were quiescent ( $70 \%$ of total recorded cells). Interestingly, the average RMP of AVPV/PeN Kiss 1 neurons from females exhibited a bimodal distribution such that the RMP of type I AVPV/PeN Kiss1 neurons was $-49.7 \pm 1.7 \mathrm{mV}$ (range: $-43 \mathrm{mV}$ to $-65 \mathrm{mV}, n=11$, Fig. $1 F$ ), which was significantly more depolarized than type II AVPV/PeN Kiss1 neurons 
$(-67.2 \pm 1.7 \mathrm{mV}$, range: $-48 \mathrm{mV}$ to -81 $\mathrm{mV} ; n=27 ; t_{(36)}=5.7 ; p<0.0005$; Fig. $1 G)$. Type II AVPV/PeN Kiss1 neurons from female mice showed a diminished input resistance, which was indicative of a higher basal conductance that may contribute to the hyperpolarized state of this cell type (type I neurons: $1.7 \pm 0.2 \mathrm{G} \Omega$, $n=11$; type II neurons: $0.9 \pm 0.1 \mathrm{G} \Omega, n=$ $\left.26, t_{(35)}=3.4 ; p<0.05\right)$. Also, type I AVPV/PeN Kiss1 neurons from female mice exhibited a decreased steady-state capacitance compared with type II neurons suggestive of an altered cell size between type I and type II AVPV/PeN Kiss1 neurons (type I neurons: $9.6 \pm 0.5 \mathrm{pF} ; n=$ 11; type II neurons: $12.1 \pm 0.6 \mathrm{pF}, n=27$, $\left.t_{(36)}=2.4 ; p<0.05\right)$.

In males, the average RMP of all AVPV/PeN Kiss1 neurons was $-56.0 \pm$ $2.9 \mathrm{mV}$ (range: $-42 \mathrm{mV}$ to $-74 \mathrm{mV}, n=$ 12 cells from 5 mice). Type I and type II AVPV/PeN Kiss1 neurons (as defined by cellular activity) were also identified in intact males. As observed in females, male type I AVPV/PeN Kiss1 neurons exhibited overshooting APs with an irregular spike frequency (range: $3.4 \pm 0.7 \mathrm{~Hz}, n=6$ ). Similar to that observed in females, the average RMP of AVPV/PeN Kiss1 neurons from males exhibited a bimodal distribution such that the RMP of type I neurons was $-48.5 \pm 1.8 \mathrm{mV}$ (range -42 $\mathrm{mV}$ to $-54 \mathrm{mV}, n=6$, Fig. $1 H$ ), while the average RMP of type II neurons was $-63.7 \pm 3.5 \mathrm{mV}$ (range: $-54 \mathrm{mV}$ to -74 $\mathrm{mV}, n=6$, Fig. $1 I$ ). However, the AP frequency of spontaneously active AVPV/ $\mathrm{PeN}$ Kiss1 neurons was higher in males compared with females $\left(t_{(15)}=2.1 ; p<\right.$

$0.05)$. Moreover, unlike that observed in females, the percentage of type I and type II AVPV/PeN Kiss1 neurons was equally distributed in males. Also, no changes in steady-state capacitance (type I $=10.5 \pm 0.7 \mathrm{pF}, n=6$; type II $=10.1 \pm 0.5 \mathrm{pF}, n=6$ ) or input resistance (type $\mathrm{I}=1.3 \pm 0.2 \mathrm{G} \Omega, n=6$; type $\mathrm{II}=1.1 \pm 0.2$ $\mathrm{G} \Omega, n=6$ ) were observed between male type I and type II AVPV/ PeN Kiss1 neurons. Together, these data support a differential regulation of AVPV/PeN Kiss1 activity and morphology between male and female mice.

$\mathrm{K}_{\mathrm{ATP}}$ channels modulate AVPV/PeN Kiss1 neuronal activity In the current study we observed that type II AVPV/PeN Kiss 1 neurons are more hyperpolarized and exhibit a decreased input resistance compared with type I AVPV/PeN Kiss1 neurons. Notably, prior work demonstrated that the inhibition of $\mathrm{K}_{\mathrm{ATP}}$ channels depolarizes $\mathrm{GnRH}$ neurons, indicating that tonic $\mathrm{K}_{\mathrm{ATP}}$ channel activity is critical for maintaining GnRH neurons in a hyperpolarized state (Zhang et al., 2007). Therefore, we asked whether $\mathrm{K}_{\mathrm{ATP}}$ channels contribute to the hyperpolarized nature of type II AVPV/PeN Kiss1 neurons. Tolbutamide $(200 \mu \mathrm{M})$ depolarized type II AVPV/PeN Kiss1 neurons by $20.3 \pm 0.6 \mathrm{mV}$, supporting the involvement of tonic $\mathrm{K}_{\mathrm{ATP}}$ channel activity at rest in this subpopulation of Kiss1 neurons ( $n=6$ from 4 female mice, RMP after tolbutamide: $-50.7 \pm 1.2 \mathrm{mV}$; Fig. $1 J, K$ ). Moreover, in the presence of tolbutamide, type II AVPV/PeN Kiss1 neurons had an input resistance of 1.6 $\pm 0.2 \mathrm{M} \Omega(n=6)$, which is statistically similar to that of type I AVPV/PeN Kiss1 neurons, suggesting that the basal activity of $\mathrm{K}_{\mathrm{ATP}}$ channels contributes to the lower input resistance of type II AVPV/PeN Kiss1 neurons.

\section{Male AVPV/PeN Kiss1 neurons showed higher EPSCs frequency}

Synaptic currents (glutamatergic and GABAergic) are important regulators of cellular activity. To investigate spontaneous glutamatergic currents, Kiss 1 neurons were recorded in voltage-clamp mode at a holding potential of $-65 \mathrm{mV}$. Inward currents from female AVPV/PeN ( $n=11$ cells from 6 mice) Kiss 1 neurons were blocked by application of the ionotropic glutamate receptor antagonists 6-cyano-7-nitroquinoxaline-2,3-dione (CNQX, 20 $\mu \mathrm{M})$ and 2-amino-5-phosphonovalerate (AP-5, $50 \mu \mathrm{M}$; Fig. 2A) and therefore were considered as spontaneous EPSCs (sEPSCs). To investigate spontaneous GABAergic currents, Kiss1 neurons were recorded at a holding potential of $-10 \mathrm{mV}$. Outward synaptic currents from AVPV/PeN ( $n=16$ cells from 11 mice) Kiss 1 neurons were blocked by picrotoxin $(50 \mu \mathrm{M})$ and therefore were 
Table 1. Synaptic properties of preoptic area (AVPV/PeN) Kiss1 neurons of females on diestrus

\begin{tabular}{lcr}
\hline AVPV/PeN & \multicolumn{1}{c}{ Type I (Firing) } & \multicolumn{1}{c}{ Type II (Quiescent) } \\
\hline EPSC frequency (Hz) & $1.0 \pm 0.3(n=10)$ & $0.9 \pm 0.1(n=20)$ \\
EPSC amplitude (pA) & $22.1 \pm 2.3(n=10)$ & $21.3 \pm 1.2(n=20)$ \\
IPSC frequency (Hz) & $0.2 \pm 0.1(n=7)$ & $0.3 \pm 0.1(n=17)$ \\
IPSC amplitude (pA) & $36.6 \pm 6.0(n=7)$ & $29.3 \pm 2.7(n=17)$ \\
\hline
\end{tabular}

Mean $\pm \mathrm{SE} ; n$ represents number of cells from 20 mice.

Table 2. Averaged fast synaptic inputs of Kiss1 neurons in the preoptic area (AVPV/ $\mathrm{PeN}$ ) and Arc nucleus of males and females

\begin{tabular}{lcc}
\hline & \multicolumn{1}{l}{ Female } & \multicolumn{1}{l}{ Male } \\
\hline AVPV/PeN & & \\
EPSC frequency (Hz) & $0.9 \pm 0.1(n=30)$ & $1.5 \pm 0.2(n=10)^{*}$ \\
EPSC amplitude (pA) & $21.6 \pm 1.1(n=30)$ & $17.7 \pm 1.4(n=10)$ \\
IPSC frequency (Hz) & $0.3 \pm 0.1(n=24)$ & $0.4 \pm 0.1(n=8)$ \\
IPSC amplitude (pA) & $31.4 \pm 2.6(n=24)$ & $24.7 \pm 1.4(n=8)$ \\
Arc & & \\
EPSC frequency (Hz) & $0.9 \pm 0.2(n=18)$ & $1.0 \pm 0.4(n=13)$ \\
EPSC amplitude (pA) & $21.7 \pm 1.6(n=18)$ & $20.6 \pm 1.5(n=13)$ \\
IPSC frequency (Hz) & $0.1 \pm 0.02(n=13)$ & $0.1 \pm 0.03(n=11)$ \\
IPSC amplitude (pA) & $26.2 \pm 3.6(n=13)$ & $38.9 \pm 7.0(n=11)$ \\
\hline
\end{tabular}

Mean \pm SE. ${ }^{*} p<0.05$. To study synaptic activity of Kiss1 neurons from females on diestrus, 30 AVPV/PeN Kiss 1 neurons from 20 mice, and 14 Arc Kiss 1 neurons from 7 mice were recorded. To study synaptic activity of Kiss 1 neurons from males 10 AVPV/PeN Kiss 1 neurons from 3 mice and 13 Arc Kiss 1 neurons from 11 mice were recorded.

identified as IPSCs (Fig. 2B). In a subset of control experiments, cesium was used as the primary cation carrier in the recording solution to block voltage-dependent and leak K conductance, which consequently improved detection of synaptic currents, especially at depolarized potentials (Hestrin et al., 1990). Unless otherwise indicated, all experiments were performed using potassium as the primary cation.

The sEPSC frequency of AVPV/PeN Kiss1 neurons from female mice was $0.9 \pm 0.1 \mathrm{~Hz}$ with a mean amplitude of $21.6 \pm 1.1$ pA ( $n=30$ cells from 20 mice). The spontaneous IPSC (sIPSC) frequency of AVPV/PeN Kiss1 neurons from female mice was $0.3 \pm 0.1 \mathrm{~Hz}$ with a mean amplitude of $31.4 \pm 2.6 \mathrm{pA}(n=24$ cells from 13 mice). No differences in synaptic activity were observed between female type I and type II AVPV/PeN Kiss1 neurons ( $p>$ 0.05; Table 1).

Male AVPV/PeN Kiss1 neurons showed a significantly higher sEPSC frequency $\left(1.5 \pm 0.2 \mathrm{~Hz}, n=10\right.$ cells from 5 mice; $t_{(38)}=$ $2.4 ; p<0.05$, Table 2 ), while the amplitude was statistically similar to that of females $\left(17.7 \pm 1.2 \mathrm{pA}, n=10 ; t_{(37)}=1.6 ; p>0.05\right.$, Table 2). No differences in mean sIPSC frequency or amplitude were apparent between males and females (Table 2).

\section{Male and female Arc Kiss1 neurons exhibit similar biophysical properties}

Within the Arc, the average RMP of female Kiss1 neurons was $-52.5 \pm 1.9 \mathrm{mV}$ (range $-43 \mathrm{mV}$ to $-67 \mathrm{mV}, n=14$ cells from 8 mice; females in diestrus). Most of the female Arc Kiss1 neurons were quiescent $(80 \%)$ while only a small percentage of the Kiss1 neurons (20\%) exhibited irregular firing patterns with a relatively low AP frequency at rest $(0.5 \pm 0.2 \mathrm{~Hz}, n=3$ out of 14 , Fig. $3 A-G)$. Unlike AVPV/PeN Kiss1 neurons, the range of RMPs from Arc Kiss1 neurons did not follow a bimodal distribution between spontaneously active and quiescent Arc Kiss1 neurons from female mice $(-49.0 \pm 0.5 \mathrm{mV}, n=3$ and $-53.4 \pm 2.3, n=$ 11 , respectively, $\left.t_{(12)}=0.9 ; p>0.05\right)$.

In males, Arc Kiss1 neurons had an average RMP of $-50.3 \pm$ $0.7 \mathrm{mV}$ (range: -43 to $-56 \mathrm{mV}, n=27$ cells from 15 mice). Similar to females in diestrus, most male Arc Kiss 1 neurons were quiescent $(63 \%)$, while a slightly higher percentage of these neurons $(37 \%)$ exhibited irregular firing patterns with a relatively low AP frequency at rest $(0.5 \pm 0.2 \mathrm{~Hz}, n=10$ out of 27$)$. In both sexes, Arc Kiss1 neurons exhibited similar steady-state capacitance (females: $8.8 \pm 0.4 \mathrm{pF}, n=14$; males: $9.7 \pm 0.4 \mathrm{pF}, n=27$ ) and input resistance (females: $1.8 \pm 0.1 \mathrm{G} \Omega, n=14$; males: $1.9 \pm$ $0.1 \mathrm{G} \Omega, n=27)$.

As observed in the AVPV/PeN, inward currents of Arc Kiss1 neurons were blocked by CNQX and AP-5 $(n=14$ cells from 7 mice), while outward synaptic currents were blocked by picrotoxin ( $n=6$ cells from 3 mice) (Fig. $2 C, D)$. Arc Kiss1 neurons from females in diestrus and males exhibited similar synaptic properties (Table 2 ).

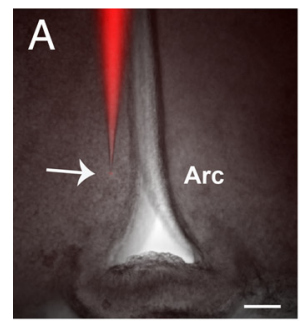

F Arc (Firing)

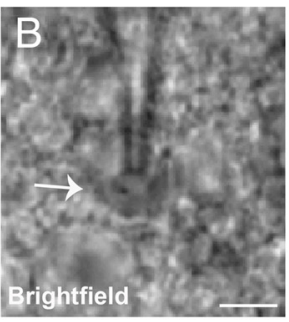

Brightfield

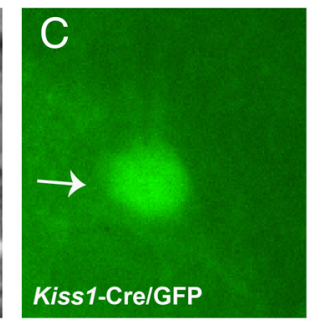

G
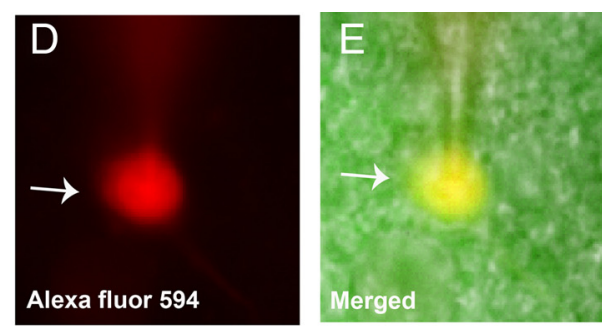

Arc (Quiescent)
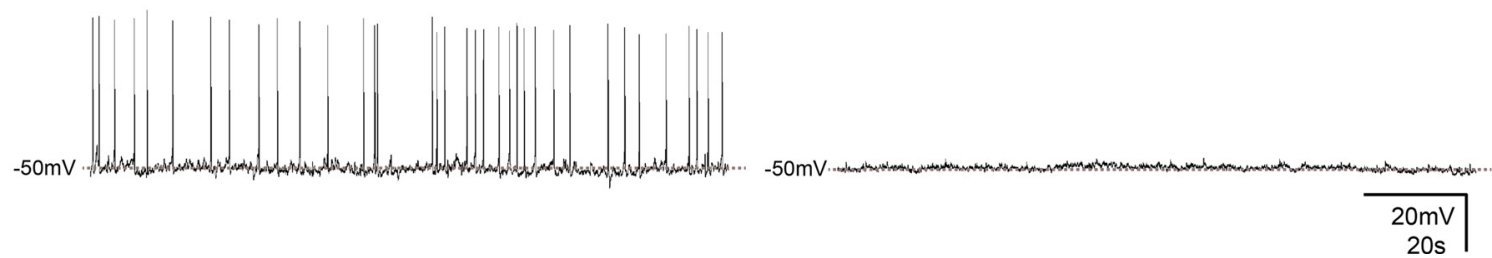

Figure 3. Biophysical properties of Arc nucleus Kiss1 neurons. $\boldsymbol{A}-\boldsymbol{E}$, Identification of recorded neuron within the Arc. $\boldsymbol{A}-\boldsymbol{E}$, Low magnification for anatomical reference (A); brightfield illumination showing a targeted neuron (B); the same neuron under fluorescent (FITC) illumination (C); complete dialysis of AlexaFluor 594 from the intracellular pipette at the end of the recording (D); colocalization of Alexa Fluor 594 and GFP $(\boldsymbol{E}) . \boldsymbol{F}, \boldsymbol{G}$, Current-clamp recording from Arc Kiss1 neurons. Scale bars: $\boldsymbol{A}, 100 \mu \mathrm{m} ; \boldsymbol{B}-\boldsymbol{E}, 10 \mu \mathrm{m}$. 
Changing levels of estrogen alters the biophysical properties and morphology of Kiss1 neurons

Kiss1 gene expression in the AVPV/PeN and Arc neurons is differentially modulated by estradiol (Smith et al., 2005b, 2007; Gottsch et al., 2009). To determine whether changing levels of estradiol also induces changes in the biophysical properties of Kiss1 neurons, AVPV/PeN and Arc Kiss1 neurons were targeted from both ovariectomized mice (OVX, $n=13$ mice) and OVX mice treated with $17 \beta$ estradiol (OVX+E2, $n=6$ mice). As expected, OVX mice showed decreased Kiss1 mRNA levels in the AVPV and increased Kiss 1 mRNA levels in the Arc, whereas OVX+E2 mice displayed an opposite pattern to that observed in OVX mice. Moreover, as previously reported (Roper et al., 1999; Christian et al., 2005; Bosch et al., 2009), uterine weights were greatly increased in OVX+E2 mice compared with OVX mice (OVX: $18.6 \pm 1.6$ mg; OVX+E2: $161.5 \pm 10.5 \mathrm{mg}, t_{(8)}=$ 13.9; $p<0.05$ ); LH levels were elevated in OVX while suppressed in OVX $+\mathrm{E} 2$ (OVX: $2.2 \pm 0.5 \mathrm{ng} / \mathrm{ml}$; OVX+E2: $0.2 \pm$ $\left.0.1 \mathrm{ng} / \mathrm{ml}, t_{(17)}=4.7 ; p<0.05\right)$. We also confirmed that E2 levels were increased in the OVX+E2 compared with OVX mice (OVX: $9.9 \pm 1.0 \mathrm{pg} / \mathrm{ml}$; OVX $+\mathrm{E} 2: 15.6 \pm$ $\left.2.0 \mathrm{pg} / \mathrm{ml}, t_{(27)}=2.6 ; p<0.05\right)$.

In current-clamp mode, type I and type II AVPV/PeN Kiss1 neurons were observed from both OVX and OVX+E2 mice. Interestingly, most of the recorded neurons from OVX mice were quiescent (type II) (85\%), whereas only half (50\%) of them were quiescent in OVX+E2 mice suggesting that E2 levels may influence the activity of Kiss1 neurons. No differences in the RMPs of type I and type II AVPV/PeN Kiss1 neurons in OVX and OVX +E2 females were detected (OVX: type I: $-53.7 \pm 1.2 \mathrm{mV}$, $n=3$ cells; type II: $-66.2 \pm 2.1, n=16$ cells; OVX + E2 type I: $-51.7 \pm 1.0 \mathrm{mV}$, $n=9$ cells; type II: $-64.5 \pm 3.7, n=9$ cells). Also, type I AVPV/PeN neurons from both OVX and OVX+E2 mice showed similar AP frequency (OVX: 0.2-2.2 Hz range, $n=3$; OVX + E2: $0.2-3.0 \mathrm{~Hz}$ range, $n=9, p>0.05)$.

Within the Arc of OVX females, 40\% of Kiss1 neurons were spontaneously active and showed a variable spike frequency $(1.3 \pm 0.4 \mathrm{~Hz}, n=11$ out 27 cells from 11 mice). Similar results were observed in OVX $+\mathrm{E} 2$ mice, where $45 \%$ of neurons were spontaneously active (spike frequency: $0.7 \pm 0.3 \mathrm{~Hz}, n=5$ out 11 cells from 6 mice). Moreover, a lack of gonadal hormones or E2 replacement failed to influence the average RMP of Kiss 1 neurons within the Arc (OVX: $-55.6 \pm 1.4 \mathrm{mV}, n=27$; OVX+E2 $-51.1 \pm 1.4 \mathrm{mV}, n=11)$. Likewise, the whole-cell input resistance of Arc Kiss1 neurons was statistically similar between OVX
AVPV

B

Arc

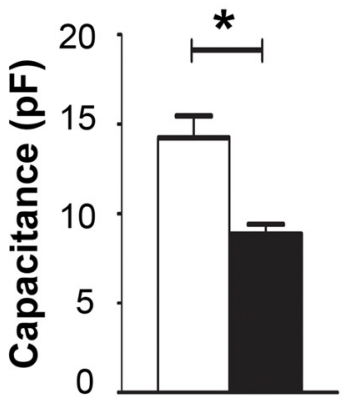

D
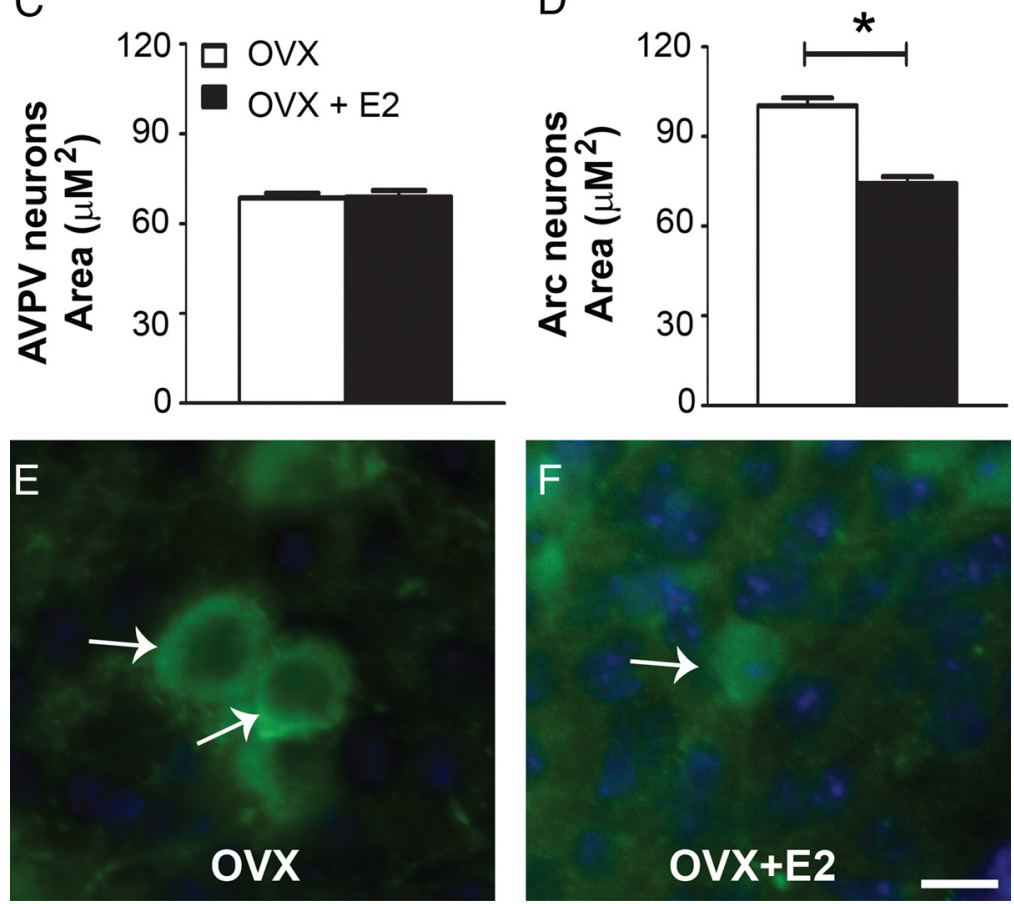

Figure 4. Changing levels of estrogen alters the biophysical properties and morphology of Kiss1 neurons. $A, B$, Bar graphs of the mean steady-state capacitance of Kiss1 neurons of the preoptic area (AVPV/PeN) and Arc nuclei. Chronic estradiol treatment $(0 V X+E 2)$ induces a significant increase in the mean steady-state capacitance of type I (firing) and type II (quiescent) AVPV/PeN induced a decrease in the mean steady-state capacitance of Arc Kiss1 neurons. C, D, Bar graphs showing the mean area of Kiss1 neurons of the AVPV/PeN (C) and Arc (D) from female mice at different estrogen milieu (ovariectomized/OVX and Kiss1 neurons from OVX mice exhibited increased neuronal area compared with OVX+E2. Data are presented as mean \pm SEM, ${ }^{*} p<0.05$. Scale bar, $10 \mu \mathrm{m}$.

and OVX+E2 females (OVX: $1.3 \pm 0.1 \mathrm{G} \Omega, n=27 ; \mathrm{OVX}+\mathrm{E} 2$ : $1.5 \pm 0.1 \mathrm{G} \Omega, n=11)$.

As gonadal steroids have the potential to mediate changes in neuronal morphology (Rometo et al., 2007; McCarthy et al., 2008; Schwarz et al., 2008), we examined steady-state capacitance, which is a measure of cell surface area, in Kiss1 neurons from OVX and OVX+E2 mice. A significant increase in the steady-state capacitance of AVPV/PeN Kiss1 neurons from OVX +E2 mice was observed (Fig. 4A). Notably, E2 replacement $(\mathrm{OVX}+\mathrm{E} 2)$ decreased the steady-state capacitance of Arc Kiss1 neurons compared with Kiss 1 neurons from OVX females (Fig. $4 B$ ). These results suggest that changing levels of E2 may modulate the morphology of Kiss1 neurons in female mice. 


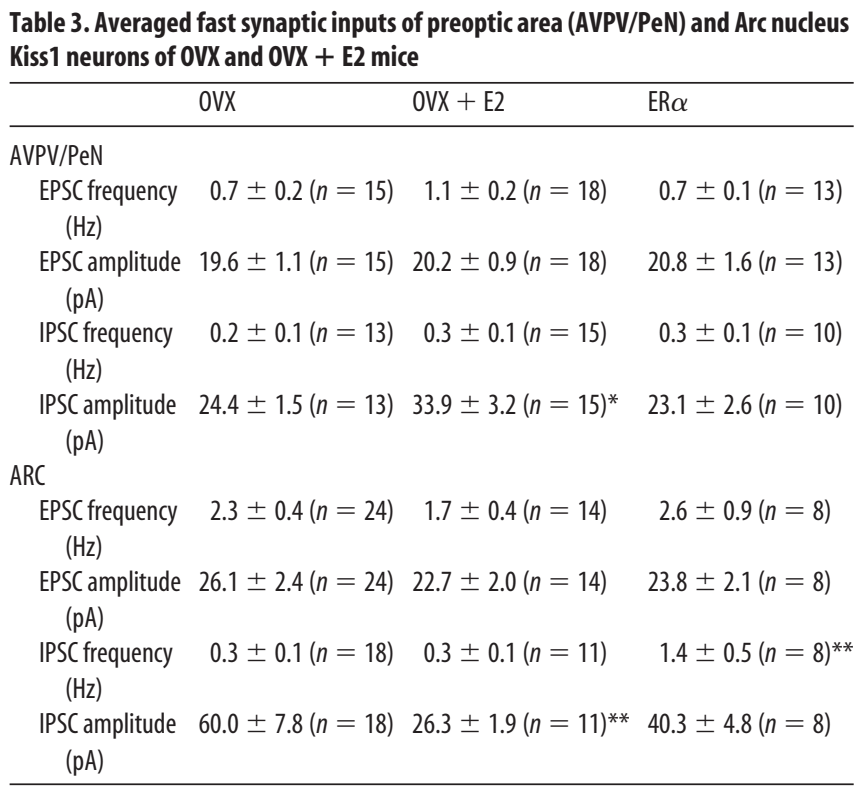

Mean $\pm S E,{ }^{*} p<0.05,{ }^{* *} p<0.005 . n$ represents number of cells. Total number of mice: OVX females, 6 for AVPV/PeN and 9 for Arc; OVX + E2 females, 6 for AVPV/PeN and 6 Arc; female Kiss1-Cre/GFP/ER $\alpha^{\text {flox/flox }}$, 4 for AVPV/PeN and 4 for Arc.

To determine whether changes in the steady-state capacitance of Kiss1 neurons were due to changes in cell morphology, brain sections of OVX and OVX +E2 mice were evaluated for changes in Kiss1-Cre/GFP neuronal area. No differences in the neuronal area of the AVPV/PeN Kiss1 neurons were observed between groups (Fig. 4C), whereas E2 replacement induced a decrease in the area of Arc Kiss1 neurons compared with OVX mice (Fig. $4 D-F)$. Together, these data provide evidence that the changes in Arc Kiss1 soma size in OVX mice are secondary to the loss of ovarian estradiol.

Analyses of the spontaneous fast synaptic activity of AVPV/ PeN Kiss1 neurons in voltage-clamp mode showed increases in sIPSC amplitude in OVX +E2 mice compared with OVX mice (Table 3), while no changes in sIPSC frequency or excitatory inputs were detected (Table 3). Interestingly, within the Arc, the sIPSC amplitude was decreased in OVX+E2 compared with OVX mice (Table 3), while the sIPSC frequency of Arc Kiss 1 neurons was similar in both conditions. The frequency and amplitude of sEPSC of Arc Kiss1 neurons were not altered by changes in the levels of gonadal steroids (Table 3).

\section{Estrogen does not enhance $\mathrm{K}_{\mathrm{ATP}}$ channel activity in Kiss1 neurons}

Recent reports have demonstrated that estrogen acutely enhances $\mathrm{K}_{\text {ATP }}$ channel activity in GnRH neurons (Zhang et al., 2007; Zhang et al., 2010). Notably, we demonstrate in the current study that $\mathrm{K}_{\mathrm{ATP}}$ channel activity contributes to the hyperpolarized state of AVPV/PeN type II neurons. To determine whether E2 acutely modulates $\mathrm{K}_{\mathrm{ATP}}$ channel activity in Kiss 1 neurons, we first examined the acute activation of $\mathrm{K}_{\mathrm{ATP}}$ channels using the ATPsensitive $\mathrm{K}^{+}$channel activator, diazoxide. AVPV/PeN and Arc Kiss1 neurons in OVX mice were voltage-clamped at a membrane potential of $-60 \mathrm{mV}$, and changes in whole-cell current in response to bath application of $200 \mu \mathrm{M}$ diazoxide were monitored in the presence of $1 \mu \mathrm{M}$ tetrodotoxin (TTX) and synaptic blockers (20 $\mu \mathrm{M}$ CNQX, $50 \mu \mathrm{M}$ Ap-5 and $50 \mu \mathrm{M}$ picrotoxin). The application of $200 \mu \mathrm{M}$ diazoxide rapidly induced an outward current of $17.2 \pm 3.8 \mathrm{pA}$ in $70 \%$ of recorded AVPV/PeN Kiss1 neurons in OVX mice ( $n=5$ out of 7 cells from 3 mice; Fig. $5 A$ ).
Interestingly, the diazoxide-induced outward current was not observed in Arc Kiss 1 neurons from OVX mice $(n=5$; cells from 3 mice Fig. $5 B$ ). In another set of experiments, 100 nM E2 was added to the bath in the presence of TTX and synaptic blockers for $15 \mathrm{~min}$, followed by the addition of $200 \mu \mathrm{M}$ diazoxide (Zhang et al., 2010). In the presence of TTX and synaptic blockers, E2 alone had no effect on the average membrane potential of AVPV/ PeN Kiss1 neurons from OVX mice. Furthermore, acute administration of E2 failed to enhance the amplitude of the outward current induced by diazoxide in AVPV/PeN Kiss1 neurons $(23.9 \pm 7.9 \mathrm{pA}, n=3$ out 5 cells from 2 mice, Fig. $5 E, F)$. In support of these data we also found that E2 (100 nM) failed to alter the RMP of AVPV/PeN Kiss1 neurons from OVX female mice independent of synaptic inputs (average RMP of all AVPV/PeN Kiss1 neurons, OVX: $-64.2 \pm 2.1 \mathrm{mV}, n=19$ cells from 9 mice; OVX + CNQX + AP5 + Picrotoxin + TTX: $-61.3 \pm 5.7 \mathrm{mV}, n=$ 6 cells from 4 mice; OVX+CNQX +AP5+Picrotoxin $+\mathrm{TTX}+\mathrm{E} 2:-64.0 \pm 2.5 \mathrm{mV}, n=6$ cells from 4 mice). Together, these data suggest that estradiol does not acutely modulate $K_{\mathrm{ATP}}$ channel activity and that estrogen does not acutely modify the cellular activity of AVPV/PeN Kiss1 neurons.

\section{Estrogen-induced changes in the biophysical properties of Kiss 1 neurons require $\operatorname{ER} \alpha$}

Estrogen effects on Kiss1 mRNA expression are disrupted in ER $\alpha$ knock-out mice (Smith et al., 2005a). To determine whether the E2-induced changes in the biophysical properties of Kiss1 neurons were dependent on $\mathrm{ER} \alpha$ we generated mice with deletion of $\mathrm{ER} \alpha$ selectively in Kiss 1 neurons. Kiss 1-Cre/GFP/ER $\alpha^{\text {flox/flox }}$ mice were generated by mating Kiss1-Cre/GFP mice with ER $\alpha^{\text {flox/flox }}$ mice (Feng et al., 2007; Xu et al., 2011). Similar to previous reports (Mayer et al., 2010), we observed that Kiss1-Cre/GFP/ $\mathrm{ER} \alpha^{\text {flox/flox }}$ females showed advanced vaginal opening $(16 \pm 2.5 \mathrm{~d}$ of age in the present study; $n=8$ ), but lack of proper sexual maturation and infertility. Interestingly, males were fertile, and, therefore, Kiss1-Cre/GFP/ER $\alpha^{\text {flox/flox }}$ male mice were used as breeders. We found that Kiss1-Cre/GFP/ER $\alpha^{\text {flox/flox }}$ female mice showed a decrease in the number of neurons expressing Kiss1 mRNA and Cre activity (visualized via GFP-ir) in the AVPV/PeN (as reported) as well as in the Arc (Fig. 6). To assess whether these findings reflect a decrease in number of Kiss1 neurons or lack of expression of Kiss 1 mRNA in a subpopulation of Arc neurons, we evaluated changes in expression of the vesicular glutamate transporter 2 (vGluT2, Slc17a6) gene, previously shown to be coexpressed in Kiss1 neurons of the Arc (Cravo et al., 2011). No difference in vGluT2 mRNA expression in the Arc was detected between OVX, OVX+E2, and Kiss1-Cre/GFP/ER $\alpha^{\text {flox/flox }}$ (ANOVA, $p=0.81$, data not shown). This observation suggests that Kiss1-Cre/GFP/ER $\alpha^{\text {flox/flox }} 35$-d-old female mice have decreased number of neurons expressing Kiss1 mRNA and Cre activity in the Arc. However, in agreement with previous studies (Mayer et al., 2010), the selective deletion of ER $\alpha$ from Kiss1 neurons induced an upregulation of Kiss1 mRNA in Arc neurons that express the Kiss1 gene (Fig. 6C). Kiss1-Cre/GFP/ER $\alpha^{\text {flox/flox }}$ females exhibited a pronounced enlargement of the uterus, high estradiol levels, and low LH levels at $35 \mathrm{~d}$ of age (Fig. $6 F-I$ ). To confirm the lack of ER $\alpha$ in Kiss1-Cre/GFP neurons, we performed immunohistochemistry on hypothalamic sections. We observed a complete lack of $\mathrm{ER} \alpha$ immunoreactivity in Kiss1-Cre/GFP neurons in the Kiss1-Cre/GFP/ER $\alpha^{\text {flox/flox }}$ mouse model (Fig. 7A-D).

The AVPV/PeN and Arc Kiss1 neurons from Kiss1-Cre/GFP/ $\mathrm{ER} \alpha^{\text {flox/flox }}$ female mice were targeted for patch-clamp recordings, and due to the high levels of estradiol present in Kiss1- 
Cre/GFP/ER $\alpha^{\text {flox/flox }}$ female mice, the data were compared with those from $\mathrm{OVX}+\mathrm{E} 2$ females (Kiss1-Cre/GFP). In current-clamp mode, type I and type II AVPV/PeN Kiss1 neurons were identified in the Kiss1-Cre/GFP/ER $\alpha^{\text {flox/flox }}$ female mice. Most of the recorded neurons were type II Kiss1 neurons (70\%). Selective deletion of $\mathrm{ER} \alpha$ failed to influence the RMPs of AVPV/PeN and Arc Kiss1 neurons (AVPV/PeN type I: $-54.0 \pm 3.1 \mathrm{mV}, n=$ 4 cells from 4 mice; type II: $-63.7 \pm 2.2$ $\mathrm{mV}, n=10$ cells from 4 mice and Arc Kiss1: $-51.6 \pm 3.2 \mathrm{mV}, n=8$ cells from 4 mice). Notably, the steady-state capacitance of female type II AVPV/PeN Kiss1 neurons of Kiss1-Cre/GFP/ER $\alpha^{\text {flox/flox }}$ mice was decreased $(10.8 \pm 0.7 \mathrm{pF}, n=$ $\left.10, t_{(17)}=2.6 ; p<0.05\right)$, while in the Arc, steady capacitance was increased (11.4 \pm $0.6 \mathrm{pF}, n=8, t=(17) 2.9 ; p<0.005)$ compared with OVX+E2 mice.

In voltage-clamp mode, AVPV/PeN Kiss1 neurons exhibited decreased sIPSC amplitude compared with OVX+E2 (23.1 \pm $2.6, n=10$ cells from 4 mice, $t(23)=2.4 ; p<0.05)$. No difference in sIPSC frequency or sEPSC frequency and amplitude was observed between Kiss1-Cre/GFP/ER $\alpha^{\text {flox/flox }}$ female and OVX+E2 mice (Table 3). However, in the Arc, the sIPSC frequency of Kiss 1 neurons from Kiss1-Cre/GFP/ER $\alpha^{\text {flox/flox }}$ mice was significantly higher compared with OVX $+\mathrm{E} 2(1.4 \pm 0.5 \mathrm{~Hz}, n=8$ cells from 4 mice, $t_{(18)}=2.6 ; p<0.005$, Fig. $\left.7 E, F\right)$ and was followed by an increase in sIPSC amplitude $(40.3 \pm 4.8, n=8)$. The frequency and amplitude of sEPSC of Arc Kiss 1 neurons were not altered by lack of ER $\alpha$. To assess whether the increase in sIPSC frequency in Arc Kiss1 neurons of Kiss1-Cre/GFP/ER $\alpha^{\text {flox/flox }}$ mice was due to altered estradiol levels, we targeted Arc Kiss1 neurons from OVX Kiss1-Cre/GFP/ER $\alpha^{\text {flox/flox }}$ female mice (35 d old, 7-10 d postOVX). No differences were observed between intact and OVX Kiss1-Cre/GFP/ER $\alpha^{\text {flox/flox }}$ in any parameter evaluated, and sIPSC remained elevated ( $\operatorname{sIPSC}$ frequency $0,9 \pm 0.3 \mathrm{~Hz}, n=9$; amplitude: $29.2 \pm 4.4 \mathrm{pA}, n=9$ cells from 3 mice, Table 4 ) compared with OVX and OVX $+\mathrm{E} 2$ mice.

Collectively, our findings demonstrate that estradiol-induced changes in biophysical properties of Kiss 1 neurons require intact ER $\alpha$ expression. In addition, our data also show that selective deletion of $\mathrm{ER} \alpha$ from Kiss1 neurons induced an increase in the inhibitory presynaptic tonus of Arc, but not AVPV/PeN, neurons.

\section{Prepubertal Kiss1 neurons are under higher presynaptic inhibitory tone}

A role for kisspeptin signaling in the onset of puberty is well defined (Herbison, 2008; Roa et al., 2008; Seminara and Crowley, 2008; Oakley et al., 2009). To determine whether the Kiss1 neurons of prepubertal females showed distinguishable cell or synaptic activity compared with adult mice, Kiss1-Cre/GFP neurons from prepubertal female mice (18-25 d of age) were evaluated. Notably, all AVPV/PeN Kiss1 neurons recorded at the prepubertal stage showed overshooting APs and a variable spike frequency $(2.3 \pm 0.4 \mathrm{~Hz}, n=10$ cells from 4 mice $)$. No bimodal distribution regarding the cell activity was observed in AVPV/PeN neurons from prepubertal female mice. The average RMP of all AVPV Kiss 1 neurons from prepubertal female mice was $-54.1 \pm 1.8$ $\mathrm{mV}(n=10$, range $-43 \mathrm{mV}$ to $-62 \mathrm{mV}$, Fig. $8 \mathrm{~A})$, which was similar to the average RMP of type I (firing) AVPV/PeN Kiss1 neurons from adult females in diestrus.

Arc Kiss 1 neurons from prepubertal female mice had an average $\mathrm{RMP}$ of $-49.3 \pm 1.3 \mathrm{mV}$ (range $-44 \mathrm{mV}$ to $-53 \mathrm{mV}, n=6$ cells from 4 animals, Fig. $8 \mathrm{~B}$ ). As reported for adult females in diestrus, most Arc Kiss1 neurons from prepubertal females were quiescent (70\%). The remaining 30\% of Arc Kiss1 neurons exhibited overshooting APs in an irregular firing pattern and an AP frequency significantly higher compared with that of Arc Kiss1 neurons recorded from adult females in diestrus $(2.5 \pm 0.2 \mathrm{~Hz}$, $t_{(3)}=4.2 ; p<0.05$, Fig. $8 C$ ). The whole-cell input resistance and steady-state capacitance of AVPV/PeN and Arc Kiss1 neurons from prepubertal females were similar to that of adult females (data not shown).

We assessed the biophysical properties of Kiss1 neurons in voltage-clamp mode to determine whether changes in synaptic activity could contribute to the excitability of those neurons in the prepubertal stage. Interestingly, AVPV/PeN Kiss1 neurons recorded from prepubertal female mice exhibited a higher sIPSC frequency compared with adult females on diestrus $(0.9 \pm 0.2$ $\mathrm{Hz}, n=8$ cells from 4 animals, $t_{(30)}=4.7 ; p<0.0001$, Fig. $8 D$ ), while no changes in sIPSC amplitude $(34.0 \pm 3.5 \mathrm{pA}, n=8)$ or excitatory inputs (sEPSC frequency: $0.9 \pm 0.2 \mathrm{~Hz}$; sEPSC amplitude: $18.0 \pm 1.6 \mathrm{pA}, n=10$ ) were detected. Likewise, Arc Kiss 1 neurons recorded from prepubertal females exhibited a slight but significant increase in sIPSC frequency $(0.3 \pm 0.1 \mathrm{~Hz}, n=6$ cells from 4 animals, $t_{(17)}=2.3 ; p<0.05$, Fig. $8 E$ ) compared with adult females, while no changes in sIPSC amplitude $(22.6 \pm 2.2$ $\mathrm{pA}, n=6$ ) or excitatory inputs were observed (sEPSC frequency: $0.9 \pm 0.2 \mathrm{~Hz}$; sEPSC amplitude: $24.9 \pm 3.2 \mathrm{pA}, n=6$ ). Our findings indicate that in female mice, prepubertal Kiss 1 neurons in the AVPV/PeN and Arc are under higher inhibitory influence compared with those of adults.

\section{Discussion}

In the present study, we used a Kiss1-Cre/GFP mouse model in which most neurons (95\%) that exhibited Cre-recombinase activity in the AVPV, PeN, and Arc also coexpressed Kiss1 mRNA. This model represents a unique tool to study the biophysical properties of the entire Kiss1 neuronal population in the hypothalamus under varying physiological/experimental conditions. 

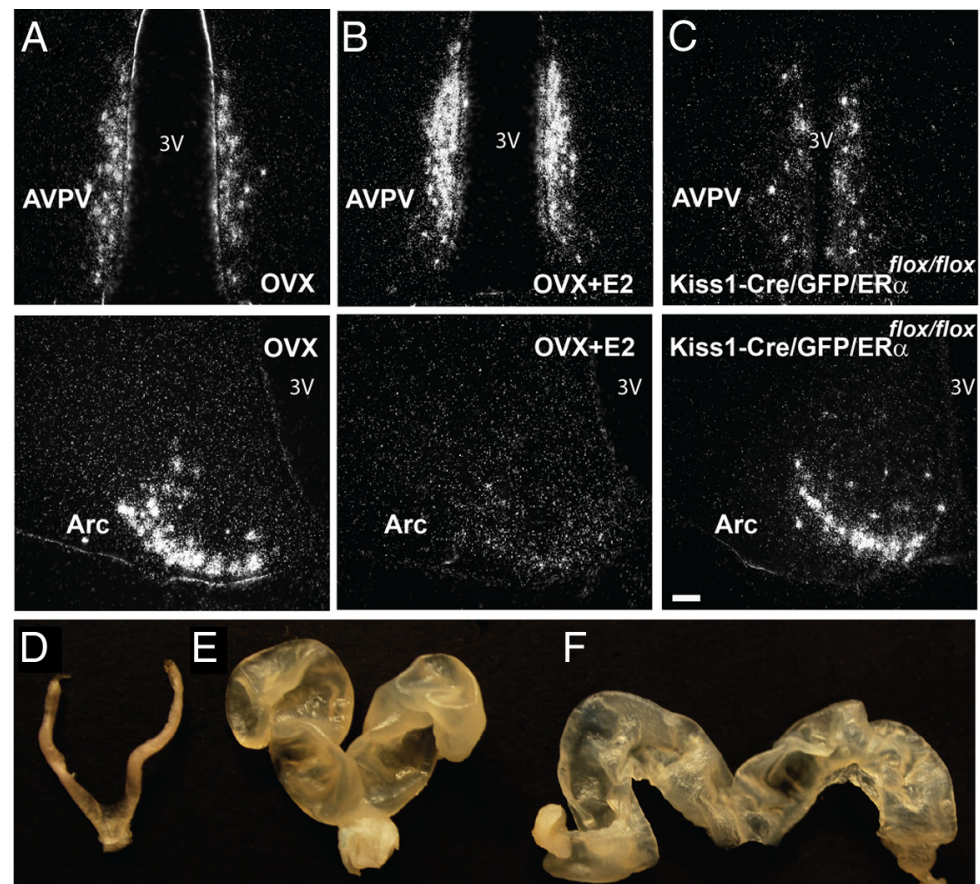

OVX

OVX+E2

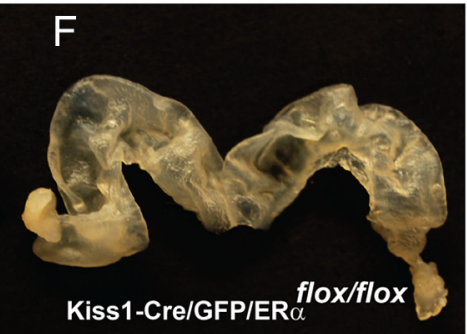

G
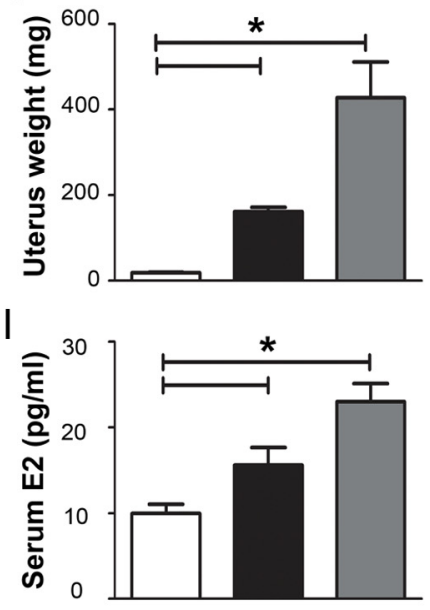

$\mathrm{H}$

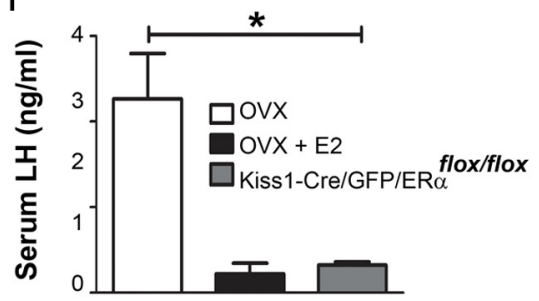

$J$

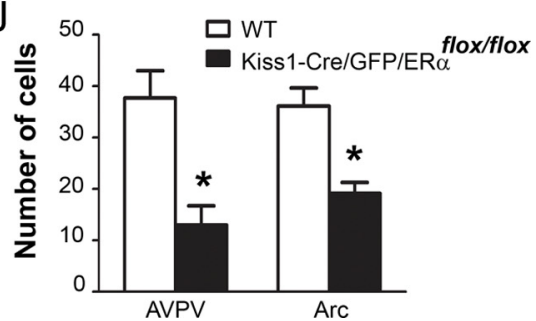

Figure 6. Selective deletion of ER $\alpha$ in Kiss1 neurons disrupts the hypothalamus-pituitary-gonadal axis. $\boldsymbol{A}-\boldsymbol{C}$, Darkfield photomicrographs of hypothalamic sections showing the distribution of Kiss1 mRNA in the AVPV and Arc nucleus. $A$, OVX mice showed decreased Kiss1 mRNA in the AVPV and increased Kiss1 mRNA in the Arc. $\boldsymbol{B}$, OVX estradiol treated (OVX+E2) mice showed increased Kiss 1 mRNA in the AVPV and decreased Kiss1 mRNA in the Arc. C, Selective deletion of ER $\alpha$ (Kiss1-Cre/GFP/ER $\alpha^{\text {flox/flox }}$ ) induced an upregulation of Kiss1 mRNA expression in the Arc. D-F, Representative image showing the uterus of OVX, OVX+E2, and Kiss1-Cre/GFP/ER $\alpha^{\text {flox/flox }}$ mice. G, Bar graphs showing the mean uterine weight. Selective deletion of ER $\alpha$ induces a profound enlargement of the uterus. $\boldsymbol{H}$, Bar graphs demonstrate the LH serum levels from OVX, OVX+E2, and Kiss1-Cre/GFP/ER $\alpha^{\text {flox/flox }}$ females. LH levels are elevated in OVX females and are decreased following chronic E2 treatment. Kiss1-Cre/GFP/ER $\alpha^{\text {flox/flox }}$ females exhibited similar levels of $\mathrm{LH}$ compared with OVX+E2. I, Bar graphs demonstrate the E2 levels from OVX, OVX+E2, and Kiss1-Cre/GFP/ER $\alpha^{\text {flox/flox }}$ females. E2 serum levels were significantly higher in OVX+E2 compared with 0VX. Kiss1-Cre/GFP/ $\mathrm{ER} \alpha^{\text {flox/flox }}$ females exhibited higher E2 levels compared with OVX or OVX+E2. J, Bar graphs of the average number of Kiss1-Cre/ GFP neurons. Kiss1-Cre/GFP/ER $\alpha^{\text {flox/flox }}$ females showed a decreased number of AVPV/PeN and Arc Kiss1 neurons compared with wild-type (WT) animals (Kiss1-Cre/GFP). Data are presented as mean \pm SEM and ${ }^{*} p<0.05$. 3V, Third ventricle. Scale bars: $\boldsymbol{A}-\boldsymbol{C}$, $50 \mu \mathrm{m} ; \boldsymbol{D}-\boldsymbol{F}, 1 \mathrm{~mm}$.

We demonstrated that AVPV/PeN Kiss1 neurons of males and females exhibit a bimodal RMP influenced by $\mathrm{K}_{\text {ATP }}$ channel activity. Moreover, the activity profiles of AVPV/PeN Kiss1 neurons suggested the presence of two neuronal populations type I (firing) and type II (quiescent). Manipulation of E2 levels changed the inhibitory tone and steadystate capacitance of AVPV/PeN and Arc Kiss1 neurons in an opposite manner. Notably, selective deletion of $\mathrm{ER} \alpha$ from Kiss1 neurons recapitulated most of the biophysical properties observed in OVX mice. We also demonstrated that prepubertal Kiss1 neurons are under higher inhibitory influence compared with adults.

Kiss1 neurons in the AVPV/PeN, but not Arc, display sexually dimorphic biophysical properties

In the AVPV/PeN, high estrogen levels stimulate Kiss1 gene expression via actions on ER $\alpha$ (Smith et al., 2005b, 2007; Gottsch et al., 2009). The AVPV is a sexually dimorphic site with a differential distribution pattern of several neurotransmitters and neuropeptides, including kisspeptin (Ottem et al., 2004; Hoffman et al., 2005; Simerly et al., 1985; Clarkson and Herbison, 2006; Kauffman et al., 2007). Interestingly, the AVPV/PeN Kiss1 neurons also displayed sexually dimorphic biophysical properties, such that neurons of males exhibited higher activity (i.e., higher APs frequency) and received higher excitatory synaptic transmission (i.e., higher sEPSC frequency). As the LH surge is absent in males, our findings suggest that, in addition to the sexually dimorphic expression of Kiss1 mRNA, differences in Kiss 1 cellular activity may underlie the striking difference in $\mathrm{GnRH}$ secretion between sexes. Further studies will be necessary to determine whether firing and quiescent AVPV/PeN Kiss1 neurons exhibit distinct chemical identities and/or site-specific projection patterns. Of note, previous studies, using cell-attached (loose patch) electrical recordings and post hoc identification of recorded neurons, found only spontaneously firing Kiss1 neurons (Ducret et al., 2010; de Croft et al., 2012). This apparent inconsistency may result from different experimental conditions employed in both studies. Importantly, since we observed type II neurons only in the AVPV/ $\mathrm{PeN}$ and not the Arc and we defined $\mathrm{K}_{\mathrm{ATP}}$ channels as being involved in this effect, we feel these new data provide an additional interesting complexity to our current understanding of Kiss1 neurons.

Male and female Arc Kiss1 neurons showed a heterogeneous pattern of cellular activity, but no bimodal distribution of RMPs. No evidence for a sexually dimorphic pattern of Arc Kiss 1 cellular activity was noticed, which is in line with a lack of difference in the distribution of Kiss1 mRNA in the Arc between sexes (Kauffman et al., 2007). 


\section{Kiss1-Cre/GFP/ER $\alpha^{\text {flox/flox }}$}
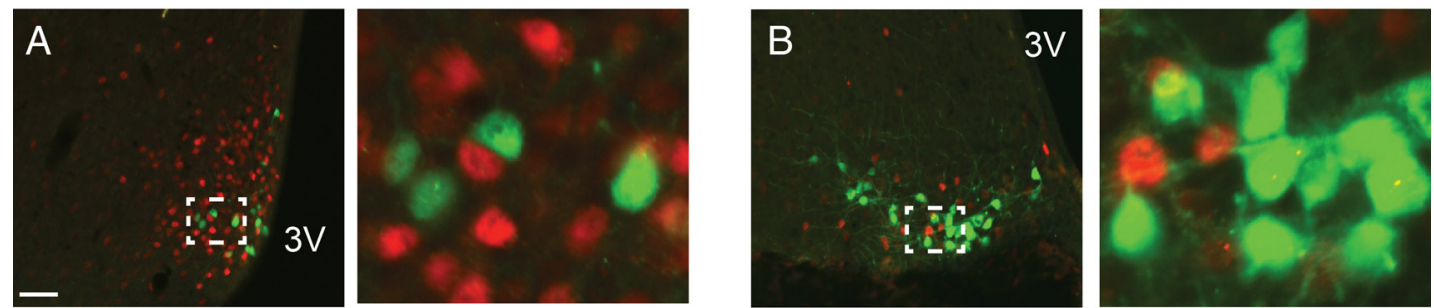

Kiss1-Cre/GFP

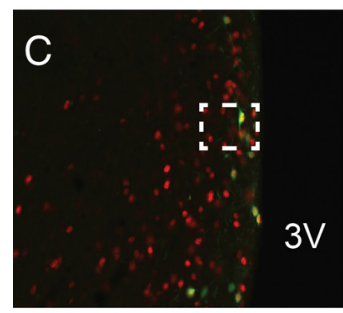

E

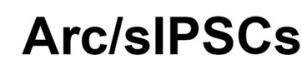

OVX+E2

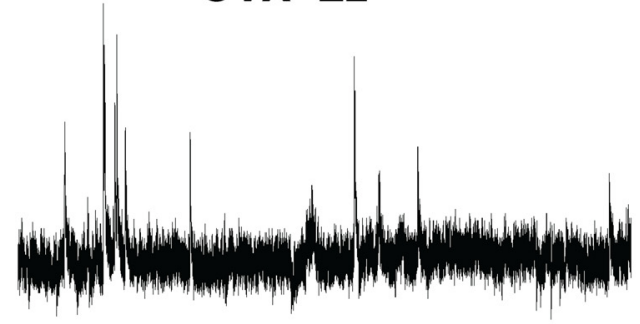

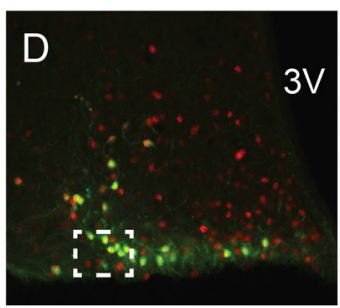

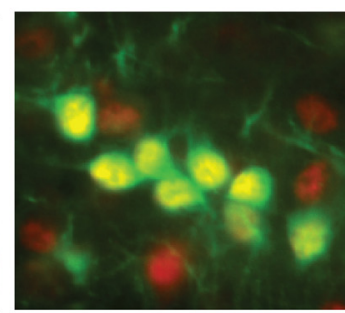

F

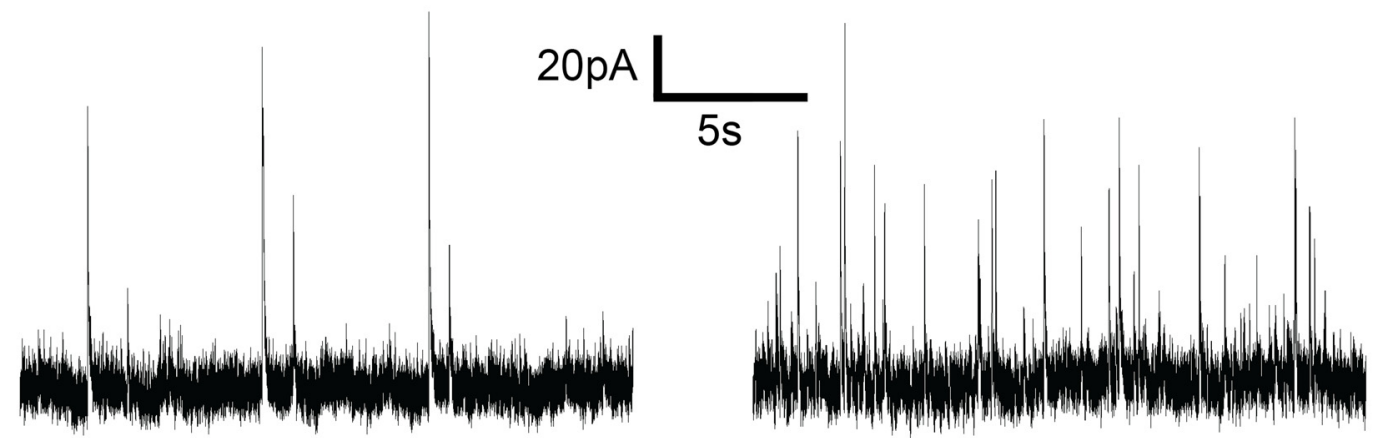

Figure 7. Estrogen effects in Kiss1 neuronal activity requires ER $\alpha$. A-D, Fluorescent photomicrographs showing the comparative distribution of Kiss1-Cre/GFP neurons (green) and ER $\alpha$ (red) immunoreactivities. Note the lack of ER $\alpha$ immunoreactivity in Kiss 1 (GFP) neurons of Kiss1-Cre/GFP/ER $\alpha^{\text {flox/flox }}(\boldsymbol{A}, \boldsymbol{B})$. $\boldsymbol{E}, \boldsymbol{F}$, Voltage-clamp recording of membrane currents at a holding potential of $-10 \mathrm{mV}$. The frequency of sIPSC of Arc Kiss1 neurons was significantly higher in the Kiss1-Cre/GFP/ER $\alpha^{\text {flox/flox }}$ female compared with $0 \mathrm{VX}+\mathrm{E} 2 \mathrm{mice}$.

\section{Table 4. Electrophysiological properties of Arc nucleus Kiss1 neurons}

\begin{tabular}{lrc}
\hline ARC & \multicolumn{1}{c}{ ER $\alpha$} & \multicolumn{1}{c}{ ER $\alpha(0 V X)$} \\
\hline RMP $(m V)$ & $-51.6 \pm 3.2(n=8)$ & $-51.6 \pm 1.6(n=10)$ \\
Input resistance (G $\Omega)$ & $1.02 \pm 0.1(n=8)$ & $1.03 \pm 0.2(n=10)$ \\
WCC (pF) & $11.4 \pm 0.6(n=8)$ & $14.4 \pm 1.6(n=8)$ \\
EPSC frequency (Hz) & $2.6 \pm 0.9(n=8)$ & $1.9 \pm 0.6(n=10)$ \\
EPSC amplitude (pA) & $23.8 \pm 2.1(n=8)$ & $19.5 \pm 1.8(n=10)$ \\
IPSC frequency (Hz) & $1.4 \pm 0.5(n=8)$ & $0.9 \pm 0.3(n=9)$ \\
IPSC amplitude (pA) & $40.3 \pm 4.8(n=8)$ & $29.2 \pm 4.4(n=9)$ \\
\hline
\end{tabular}

Mean $\pm S E, n$ representes number of cells. Total number of mice: female Kiss1-Cre/GFP/ER $\alpha^{\text {flox/flox }}, 4$ mice for AVPV/PeN and 4 for Arc; ovariectomized Kiss1-Cre/GFP/ER $\alpha^{\text {flox/flox }}, 3$ mice for AVPV/PeN and 3 for Arc.
Estradiol milieu modulates Kiss1 neuronal activity

The AVPV is a crucial site for the positive feedback action of estrogen, and Kiss1 neurons are thought to mediate this effect (Levine and Ramirez, 1982; Levine et al., 1982; Wiegand and Terasawa, 1982; Moenter et al., 1992a; Caraty et al., 1995; Herbison, 2008). We further assessed whether changing circulating levels of estrogen modulate Kiss1 cell activity. Kiss1 neurons under lack of negative estrogen feedback action (i.e., OVX) and in the presence of the negative estrogen feedback action (i.e., $\mathrm{OVX}+\mathrm{E} 2$ ) were targeted for electrophysiological recording. Interestingly, E2 modulated the inhibitory tone of AVPV/PeN and Arc Kiss1 neurons in an opposite manner. Whether these effects are directly involved in the physiological actions of kisspeptin on 
A

\section{AVPV (Prepubertal)}

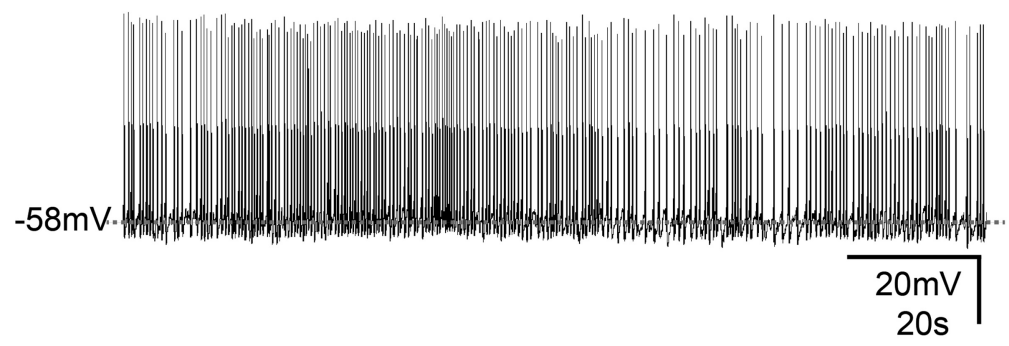

B

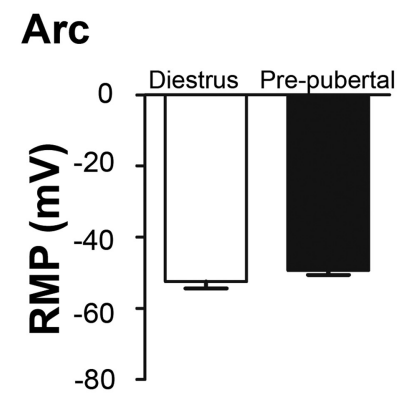

D

Diestrus

\section{AVPVIsIPSCs}

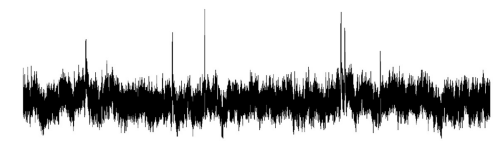

C

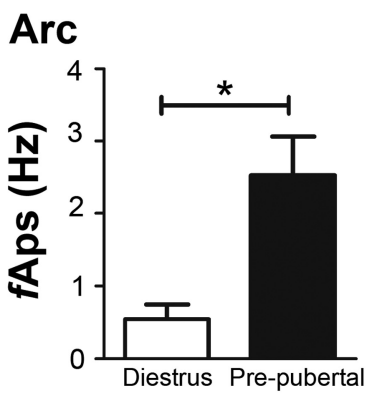

Prepubertal

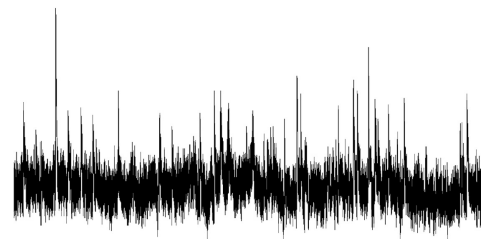

E

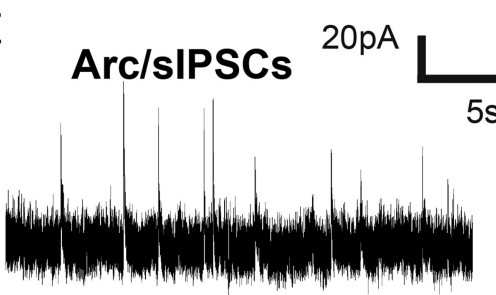

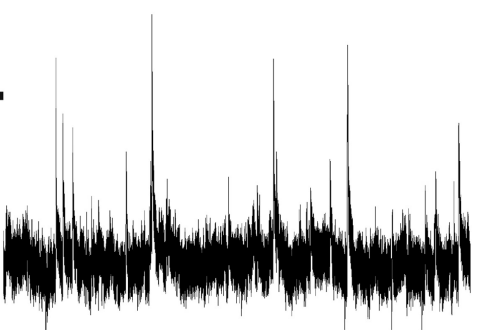

Figure 8. Prepubertal Kiss1 neurons are under higher presynaptic inhibitory tone. $\boldsymbol{A}$, Representative current-clamp recording from a Kiss1 neuron in the AVPV. All AVPV Kiss1 neurons recorded at prepubertal stage exhibited overshooting action potentials. $\boldsymbol{B}$, Bar graph summarizing the averaged RMP of Kiss 1 neurons of the Arc nucleus. The RMP of Arc Kiss1 neurons from prepubertal female mice were similar to adult females. $C$, The frequency of action potentials ( fAPs) of Arc Kiss1 neurons recorded from prepubertal female mice was significantly higher compared with females on diestrus. $\boldsymbol{D}-\boldsymbol{E}$, Representative voltage-clamp recordings demonstrates that AVPV/PeN $(\boldsymbol{D})$ and Arc Kiss1 neurons $(\boldsymbol{E})$ recorded from prepubertal female mice exhibited higher frequency of sIPSC compared with females on diestrus. Data are presented as mean \pm SEM, ${ }^{*} p<0.05$.

LH secretion still needs to be directly tested but our electrophysiological data support the proposed distinct roles of both neuronal populations in the positive $(\mathrm{AVPV} / \mathrm{PeN})$ and negative (Arc) feedback actions of estrogen in adult female mice (Smith et al., 2005b; Dungan et al., 2006; Popa et al., 2008; Gottsch et al., 2009).

Firing and quiescent Kiss1 neurons were detected in the AVPV/PeN and Arc of females in different estrogen milieus. Similar results were described for Arc Kiss1 neurons from OVX mice, identified in a Kiss1-Cre/GFP knockin mouse model (Gottsch et al., 2011). However, notably, while the pattern of distribution of these two types of neurons did not change in the Arc, the distribution of firing and quiescent AVPV/PeN Kiss1 neurons shifted from a higher percentage of quiescent neurons in the OVX group to an increase in the percentage of firing neurons in the OVX+E2 group. These findings indicate that estrogen levels dictate the activity of specific subsets of Kiss1 neurons.

Changing levels of $\mathrm{E} 2$ also altered the steady-state capacitance of AVPV/PeN and Arc Kiss1 neurons in an opposite manner. In the Arc we observed a rapid change in Kiss1 soma size following E2 manipulation, and, therefore, our electrophysiological data in mice corroborate previous studies showing that lack of gonadal steroids induces a pronounced enlargement of Kiss1 neurons in the Arc of ovariectomized monkeys and of postmenopausal women (Rometo et al., 2007). Intriguingly, we were not able to detect changes in AVPV/PeN Kiss1 soma size as predicted by the steady-state capacitance. The reason for this apparent discrepancy is not clear, but we speculate that the difficulty in discriminating between type I and type II neurons in histological sections may account for the variance in morphological assessments. In addition, measurement of soma area may have underestimated the total cell surface area including the dendritic trees. Interestingly, $\mathrm{E} 2$ treatment rapidly restored AVPV/PeN and Arc cell steady-state capacitance and Arc Kiss1 soma size of OVX females, indicating the existence of a plastic neuronal modulation across the estrous cycles.

\section{Changes in Kiss1 neuronal activity require $\mathrm{ER} \alpha$} Estrogen effects in Kiss1 mRNA expression are mediated by ER $\alpha$ (Smith et al., 2005a). Thus, we further assessed the $\mathrm{ER} \alpha$ dependent actions of estradiol on Kiss1 neuronal activity. As previously described, female mice with selective deletion of $\operatorname{ER} \alpha$ from Kiss1 neurons showed advanced puberty, ovarian deficits, and a decreased number of Kiss1 neurons in the AVPV/PeN (Mayer et al., 2010). In addition, we observed that at $35 \mathrm{~d}$ of age, these mice displayed high circulating levels of estradiol that likely explain the striking increase in their uterus size. Moreover, the Cre-activity in our mouse model combined to Kiss 1 and vGluT2 mRNA allowed us to detect differences in the number of Arc neurons expressing Kiss1, suggesting that the full expression of Kiss 1 in hypothalamic neurons is compromised in this model. The selective deletion of $\mathrm{ER} \alpha$ from Kiss1 neurons induced an electrophysiological pattern similar to that observed in OVX females. Because circulating levels of estradiol were overtly increased in this mouse model, our 
findings indicate a lack of sensing or responding to changing levels of estradiol. In several neuronal populations, E2 activates membrane-associated receptors and initiates intracellular signaling pathways that culminate in relatively rapid, non-genomic effects (Zhang et al., 2007, 2010; Malyala et al., 2008). However, E2 did not exert acute action potential dependent effects on the activity of AVPV/PeN Kiss1 neurons, suggesting that it acts at the genomic level. Thus, ER $\alpha$ may drive expression of genes involved in the modulation of cell activity. One example is the $\mathrm{K}_{\mathrm{ATP}}$ channel, which is expressed in hypothalamic neurons implicated in the regulation of GnRH secretion (DunnMeynell et al., 1998). Interestingly, in a chronic sex steroid treatment paradigm, the expression of the $\mathrm{K}_{\mathrm{ATP}}$ channel subunit Kir6.2 was increased in the preoptic area, but not in the mediobasal hypothalamus, and tolbutamide enhanced the frequency of pulsatile LH secretion (Huang et al., 2008). In agreement, $\mathrm{K}_{\mathrm{ATP}}$ channels specifically modulated AVPV/PeN, but not Arc, Kiss1 neuronal activity.

\section{Developing Kiss1 neurons are under higher inhibitory presynaptic tone}

Studies have suggested that prepubertal GnRH neurons are under higher inhibitory restraint and/or under decreased excitatory influence (Clarkson and Herbison, 2006; Ojeda et al., 2006). Importantly, kisspeptin modulates $\mathrm{GnRH}$ neuronal responses to GABA and glutamate (Pielecka-Fortuna and Moenter, 2010) and thereby may modulate GnRH excitability across pubertal maturation. However, what determines the physiological changes in Kiss1-GPR54 system remains undefined. In the AVPV/PeN, these changes are thought to be driven by altered estrogen levels, consequent to pubertal initiation, as these responses can be blocked by ovariectomy or deletion of aromatase or ER $\alpha$ (Smith et al., 2005a; Bakker et al., 2010; Mayer et al., 2010). On the other hand, lack of estrogen signaling in Arc Kiss1 neurons disrupts the pubertal brake causing an anticipation of puberty onset (Mayer et al., 2010). We demonstrate here that prepubertal AVPV/PeN and Arc Kiss 1 neurons exhibit higher inhibitory presynaptic activity. Previous studies in primate have demonstrated that puberty can be induced by pharmacological removal of GABA inhibition (Mitsushima et al., 1994), a response partially mediated by GABAergic effects upon Kisspeptin neurons (Kurian et al., 2012). Therefore, our findings indicate that inhibitory inputs to Kiss 1 neurons are key components of pubertal maturation.

In summary, our findings indicate that estrogen-dependent shift in Kiss1 neuronal activity underlies kisspeptin action in female reproduction, an effect that requires intact ER $\alpha$ signaling. Importantly, our study also reveals that prepubertal Kiss1 neurons are under presynaptic inhibitory control. Release of this neural restraint may represent a fundamental physiological event in pubertal initiation.

\section{References}

Apter D, Bützow TL, Laughlin GA, Yen SS (1993) Gonadotropin-releasing hormone pulse generator activity during pubertal transition in girls: pulsatile and diurnal patterns of circulating gonadotropins. J Clin Endocrinol Metab 76:940-949. CrossRef Medline

Bakker J, Pierman S, González-Martínez D (2010) Effects of aromatase mutation (ArKO) on the sexual differentiation of kisspeptin neuronal numbers and their activation by same versus opposite sex urinary pheromones. Horm Behav 57:390-395. CrossRef Medline

Bosch MA, Hou J, Fang Y, Kelly MJ, RØnnekleiv OK (2009) $17 \beta$-estradiol regulation of the mRNA expression of t-type calcium channel subunits: Role of estrogen receptor $\alpha$ and estrogen receptor $\beta$. J Comp Neurol 512:347-358. CrossRef
Brann DW, Mahesh VB (1994) Excitatory amino acids: function and significance in reproduction and neuroendocrine regulation. Front Neuroendocrinol 15:3-49. CrossRef Medline

Caraty A, Evans NP, Fabre-Nys CJ, Karsch EJ (1995) The preovulatory gonadotrophin-releasing hormone surge: a neuroendocrine signal for ovulation. J Reprod Fertil Suppl 49:245-255. Medline

Christian CA, Moenter SM (2007) Estradiol induces diurnal shifts in GABA transmission to gonadotropin-releasing hormone neurons to provide a neural signal for ovulation. J Neurosci 27:1913-1921. CrossRef Medline

Christian CA, Mobley JL, Moenter SM (2005) Diurnal and estradioldependent changes in gonadotropin-releasing hormone neuron firing activity. Proc Natl Acad Sci U S A 102:15682-15687. CrossRef Medline

Clarkson J, Herbison AE (2006) Postnatal development of kisspeptin neurons in mouse hypothalamus; sexual dimorphism and projections to gonadotropinreleasing hormone neurons. Endocrinology 147:5817-5825. CrossRef Medline

Cookson J, Hodgson R, Wildgust HJ (2012) Prolactin, hyperprolactinaemia and antipsychotic treatment: a review and lessons for treatment of early psychosis. J Psychopharmacol 26:42-51. CrossRef Medline

Cravo RM, Margatho LO, Osborne-Lawrence S, Donato J Jr, Atkin S, Bookout AL, Rovinsky S, Frazão R, Lee CE, Gautron L, Zigman JM, Elias CF (2011) Characterization of Kiss1 neurons using transgenic mouse models. Neuroscience 173:37-56. CrossRef Medline

d'Anglemont de Tassigny X, Fagg LA, Dixon JP, Day K, Leitch HG, Hendrick AG, Zahn D, Franceschini I, Caraty A, Carlton MB, Aparicio SA, Colledge WH (2007) Hypogonadotropic hypogonadism in mice lacking a functional Kiss1 gene. Proc Natl Acad Sci U S A 104:10714-10719. CrossRef Medline

de Croft S, Piet R, Mayer C, Mai O, Boehm U, Herbison AE (2012) Spontaneous kisspeptin neuron firing in the adult mouse reveals marked sex and brain region differences but no support for a direct role in negative feedback. Endocrinology 153:5384-5393. CrossRef Medline

de Roux N, Genin E, Carel JC, Matsuda F, Chaussain JL, Milgrom E (2003) Hypogonadotropic hypogonadism due to loss of function of the KiSS1derived peptide receptor GPR54. Proc Natl Acad Sci U S A 100:1097210976. CrossRef Medline

Ducret E, Gaidamaka G, Herbison AE (2010) Electrical and morphological characteristics of anteroventral periventricular nucleus kisspeptin and other neurons in the female mouse. Endocrinology 151:2223-2232. CrossRef Medline

Dungan HM, Clifton DK, Steiner RA (2006) Minireview: kisspeptin neurons as central processors in the regulation of gonadotropin-releasing hormone secretion. Endocrinology 147:1154-1158. Medline

Dunn-Meynell AA, Rawson NE, Levin BE (1998) Distribution and phenotype of neurons containing the ATP-sensitive $\mathrm{K}+$ channel in rat brain. Brain Res 814:41-54. CrossRef Medline

Feng Y, Manka D, Wagner KU, Khan SA (2007) Estrogen receptor- $\alpha$ expression in the mammary epithelium is required for ductal and alveolar morphogenesis in mice. Proc Natl Acad Sci U S A 104:14718-14723. CrossRef Medline

Funes S, Hedrick JA, Vassileva G, Markowitz L, Abbondanzo S, Golovko A, Yang S, Monsma FJ, Gustafson EL (2003) The KiSS-1 receptor GPR54 is essential for the development of the murine reproductive system. Biochem Biophys Res Comm 312:1357-1363. CrossRef Medline

Gavériaux-Ruff C, Kieffer BL (2007) Conditional gene targeting in the mouse nervous system: Insights into brain function and diseases. Pharmacol Ther 113:619-634. CrossRef Medline

Gottsch ML, Navarro VM, Zhao Z, Glidewell-Kenney C, Weiss J, Jameson JL, Clifton DK, Levine JE, Steiner RA (2009) Regulation of Kiss1 and dynorphin gene expression in the murine brain by classical and nonclassical estrogen receptor pathways. J Neurosci 29:9390-9395. CrossRef Medline

Gottsch ML, Popa SM, Lawhorn JK, Qiu J, Tonsfeldt KJ, Bosch MA, Kelly MJ, Rønnekleiv OK, Sanz E, McKnight GS, Clifton DK, Palmiter RD, Steiner RA (2011) Molecular properties of Kiss1 neurons in the arcuate nucleus of the mouse. Endocrinology 152:4298-4309. CrossRef Medline

Han SK, Gottsch ML, Lee KJ, Popa SM, Smith JT, Jakawich SK, Clifton DK, Steiner RA, Herbison AE (2005) Activation of gonadotropin-releasing hormone neurons by kisspeptin as a neuroendocrine switch for the onset of puberty. J Neurosci 25:11349-11356. CrossRef Medline

Herbison AE (2008) Estrogen positive feedback to gonadotropin-releasing hormone $(\mathrm{GnRH})$ neurons in the rodent: The case for the rostral periven- 
tricular area of the third ventricle (RP3V). Brain Res Rev 57:277-287. Medline

Herbison AE, Pape JR (2001) New evidence for estrogen receptors in gonadotropin-releasing hormone neurons. Front Neuroendocrinol 22: 292-308. CrossRef Medline

Herbison AE, Porteous R, Pape JR, Mora JM, Hurst PR (2008) Gonadotropinreleasing hormone neuron requirements for puberty, ovulation, and fertility. Endocrinology 149:597-604. Medline

Hestrin S, Nicoll RA, Perkel DJ, Sah P (1990) Analysis of excitatory synaptic action in pyramidal cells using whole-cell recording from rat hippocampal slices. J Physiol 422:203-225. Medline

Hill JW, Williams KW, Ye C, Luo J, Balthasar N, Coppari R, Cowley MA, Cantley LC, Lowell BB, Elmquist JK (2008) Acute effects of leptin require PI3K signaling in hypothalamic proopiomelanocortin neurons in mice. J Clin Invest 118:1796-1805. CrossRef Medline

Hoffman GE, Le WW, Schulterbrandt T, Legan SJ (2005) Estrogen and progesterone do not activate Fos in AVPV or LHRH neurons in male rats. Brain Res 1054:116-124. CrossRef Medline

Huang W, Acosta-Martínez M, Levine JE (2008) Ovarian steroids stimulate adenosine triphosphate-sensitive potassium (KATP) channel subunit gene expression and confer responsiveness of the gonadotropin-releasing hormone pulse generator to KATP channel modulation. Endocrinology 149:2423-2432. CrossRef Medline

Irwig MS, Fraley GS, Smith JT, Acohido BV, Popa SM, Cunningham MJ, Gottsch ML, Clifton DK, Steiner RA (2004) Kisspeptin activation of gonadotropin releasing hormone neurons and regulation of KiSS-1 mRNA in the male rat. Neuroendocrinology 80:264-272. CrossRef Medline

Kauffman AS, Gottsch ML, Roa J, Byquist AC, Crown A, Clifton DK, Hoffman GE, Steiner RA, Tena-Sempere M (2007) Sexual differentiation of Kiss1 gene expression in the brain of the rat. Endocrinology 148:17741783. Medline

Kurian JR, Keen KL, Guerriero KA, Terasawa E (2012) Tonic control of kisspeptin release in prepubertal monkeys: implications to the mechanism of puberty onset. Endocrinology 153:3331-3336. CrossRef Medline

Lapatto R, Pallais JC, Zhang D, Chan YM, Mahan A, Cerrato F, Le WW, Hoffman GE, Seminara SB (2007) Kiss 1-/- mice exhibit more variable hypogonadism than Gpr54-/- mice. Endocrinology 148:4927-4936. CrossRef Medline

Levine JE, Ramirez VD (1982) Luteinizing hormone-releasing hormone release during the rat estrous cycle and after ovariectomy, as estimated with push-pull cannulae. Endocrinology 111:1439-1448. CrossRef Medline

Levine JE, Pau KY, Ramirez VD, Jackson GL (1982) Simultaneous measurement of luteinizing hormone-releasing hormone and luteinizing hormone release in unanesthetized, ovariectomized sheep. Endocrinology 111:1449-1455. CrossRef Medline

Malyala A, Zhang C, Bryant DN, Kelly MJ, Rønnekleiv OK (2008) PI3K signaling effects in hypothalamic neurons mediated by estrogen. J Comp Neurol 506:895-911. CrossRef Medline

Mayer C, Acosta-Martinez M, Dubois SL, Wolfe A, Radovick S, Boehm U, Levine JE (2010) Timing and completion of puberty in female mice depend on estrogen receptor $\alpha$-signaling in kisspeptin neurons. Proc Natl Acad Sci U S A 107:22693-22698. CrossRef Medline

McCarthy MM, Schwarz JM, Wright CL, Dean SL (2008) Mechanisms mediating oestradiol modulation of the developing brain. J Neuroendocrinol 20:777-783. CrossRef Medline

Mitsushima D, Hei DL, Terasawa E (1994) gamma-Aminobutyric acid is an inhibitory neurotransmitter restricting the release of luteinizing hormone-releasing hormone before the onset of puberty. Proc Natl Acad Sci U S A 91:395-399. CrossRef Medline

Moenter SM, Brand RM, Midgley AR, Karsch FJ (1992a) Dynamics of gonadotropin-releasing hormone release during a pulse. Endocrinology 130:503-510. CrossRef Medline

Moenter SM, Brand RC, Karsch FJ (1992b) Dynamics of gonadotropinreleasing hormone $(\mathrm{GnRH})$ secretion during the $\mathrm{GnRH}$ surge: insights into the mechanism of GnRH surge induction. Endocrinology 130:29782984. CrossRef Medline

Moenter SM, Chu Z, Christian CA (2009) Neurobiological mechanisms underlying oestradiol negative and positive feedback regulation of gonadotrophin-releasing hormone neurones. J Neuroendocrinol 21:327333. CrossRef Medline

Navarro VM, Castellano JM, Fernández-Fernández R, Barreiro ML, Roa J, Sanchez-Criado JE, Aguilar E, Dieguez C, Pinilla L, Tena-Sempere M
(2004) Developmental and hormonally regulated messenger ribonucleic acid expression of KiSS-1 and its putative receptor, GPR54, in rat hypothalamus and potent luteinizing hormone-releasing activity of KiSS-1 peptide. Endocrinology 145:4565-4574. CrossRef Medline

Oakley AE, Clifton DK, Steiner RA (2009) Kisspeptin signaling in the brain. Endocr Rev 30:713-743. CrossRef Medline

Ojeda SR, Lomniczi A, Mastronardi C, Heger S, Roth C, Parent AS, Matagne V, Mungenast AE (2006) Minireview: the neuroendocrine regulation of puberty: is the time ripe for a systems biology approach? Endocrinology 147:1166-1174. Medline

Ottem EN, Godwin JG, Krishnan S, Petersen SL (2004) Dual-phenotype GABA/glutamate neurons in adult preoptic area: sexual dimorphism and function. J Neurosci 24:8097-8105. CrossRef Medline

Petersen SL, Ottem EN, Carpenter CD (2003) Direct and indirect regulation of gonadotropin-releasing hormone neurons by estradiol. Biol Reprod 69:1771-1778. CrossRef Medline

Pielecka-Fortuna J, Moenter SM (2010) Kisspeptin increases \{gamma\}aminobutyric acidergic and glutamatergic transmission directly to gonadotropin-releasing hormone neurons in an estradiol-dependent manner. Endocrinology 151:291-300. CrossRef Medline

Pielecka-Fortuna J, Chu Z, Moenter SM (2008) Kisspeptin acts directly and indirectly to increase gonadotropin-releasing hormone neuron activity and its effects are modulated by estradiol. Endocrinology 149: 1979-1986. CrossRef Medline

Plant TM (2001) Leptin, growth hormone, and the onset of primate puberty. J Clin Endocrinol Metab 86:458 -460. CrossRef Medline

Plant TM, Barker-Gibb ML (2004) Neurobiological mechanisms of puberty in higher primates. Hum Reprod Update 10:67-77. CrossRef Medline

Popa SM, Clifton DK, Steiner RA (2008) The role of kisspeptins and GPR54 in the neuroendocrine regulation of reproduction. Annu Rev Physiol 70:213-238. CrossRef Medline

Roa J, Aguilar E, Dieguez C, Pinilla L, Tena-Sempere M (2008) New frontiers in kisspeptin/GPR54 physiology as fundamental gatekeepers of reproductive function. Front Neuroendocrinol 29:48-69. CrossRef Medline

Rometo AM, Krajewski SJ, Voytko ML, Rance NE (2007) Hypertrophy and increased kisspeptin gene expression in the hypothalamic infundibular nucleus of postmenopausal women and ovariectomized monkeys. J Clin Endocrinol Metab 92:2744-2750. CrossRef Medline

Roper RJ, Griffith JS, Lyttle CR, Doerge RW, McNabb AW, Broadbent RE, Teuscher C (1999) Interacting quantitative trait loci control phenotypic variation in murine estradiol-regulated responses. Endocrinology 140: 556-561. CrossRef Medline

Schwarz JM, Liang SL, Thompson SM, McCarthy MM (2008) Estradiol induces hypothalamic dendritic spines by enhancing glutamate release: a mechanism for organizational sex differences. Neuron 58:584-598. CrossRef Medline

Scott MM, Lachey JL, Sternson SM, Lee CE, Elias CF, Friedman JM, Elmquist JK (2009) Leptin targets in the mouse brain. J Comp Neurol 514:518 532. CrossRef Medline

Seminara SB, Crowley WF Jr (2008) Kisspeptin and GPR54: discovery of a novel pathway in reproduction. J Neuroendocrinol 20:727-731. CrossRef Medline

Seminara SB, Messager S, Chatzidaki EE, Thresher RR, Acierno JS Jr, Shagoury JK, Bo-Abbas Y, Kuohung W, Schwinof KM, Hendrick AG, Zahn D, Dixon J, Kaiser UB, Slaugenhaupt SA, Gusella JF, O'Rahilly S, Carlton MB, Crowley WF Jr, Aparicio SA, Colledge WH (2003) The GPR54 gene as a regulator of puberty. $\mathrm{N}$ Engl J Med 349:1614-1627. CrossRef Medline

Shahab M, Mastronardi C, Seminara SB, Crowley WF, Ojeda SR, Plant TM (2005) Increased hypothalamic GPR54 signaling: a potential mechanism for initiation of puberty in primates. Proc Natl Acad Sci U S A 102:21292134. CrossRef Medline

Simerly RB, Swanson LW, Gorski RA (1985) The distribution of monoaminergic cells and fibers in a periventricular preoptic nucleus involved in the control of gonadotropin release: Immunohistochemical evidence for a dopaminergic sexual dimorphism. Brain Res 330:55-64. CrossRef Medline

Sisk CL, Foster DL (2004) The neural basis of puberty and adolescence. Nat Neurosci 7:1040-1047. CrossRef Medline

Smith JT, Dungan HM, Stoll EA, Gottsch ML, Braun RE, Eacker SM, Clifton DK, Steiner RA (2005a) Differential regulation of KiSS-1 mRNA expres- 
sion by sex steroids in the brain of the male mouse. Endocrinology 146: 2976-2984. CrossRef Medline

Smith JT, Cunningham MJ, Rissman EF, Clifton DK, Steiner RA (2005b) Regulation of Kiss 1 gene expression in the brain of the female mouse. Endocrinology 146:3686-3692. CrossRef Medline

Smith JT, Clay CM, Caraty A, Clarke IJ (2007) KiSS-1 messenger ribonucleic acid expression in the hypothalamus of the ewe is regulated by sex steroids and season. Endocrinology 148:1150-1157. Medline

Styne DM (1994) Physiology of puberty. Horm Res 41 Suppl 2:3-6. Medline

Topaloglu AK, Tello JA, Kotan LD, Ozbek MN, Yilmaz MB, Erdogan S, Gurbuz F, Temiz F, Millar RP, Yuksel B (2012) Inactivating KISS1 mutation and hypogonadotropic hypogonadism. N Engl J Med 366: 629-635. CrossRef Medline

Wiegand SJ, Terasawa E (1982) Discrete lesions reveal functional heterogeneity of suprachiasmatic structures in regulation of gonadotropin secretion in the female rat. Neuroendocrinology 34:395-404. CrossRef Medline

Williams KW, Margatho LO, Lee CE, Choi M, Lee S, Scott MM, Elias CF, Elmquist JK (2010) Segregation of acute leptin and insulin effects in distinct populations of arcuate proopiomelanocortin neurons. J Neurosci 30:2472-2479. CrossRef Medline

Wintermantel TM, Campbell RE, Porteous R, Bock D, Gröne HJ, Todman MG,
Korach KS, Greiner E, Pérez CA, Schütz G, Herbison AE (2006) Definition of estrogen receptor pathway critical for estrogen positive feedback to gonadotropin-releasing hormone neurons and fertility. Neuron 52:271-280. CrossRef Medline

Wu FC, Butler GE, Kelnar CJ, Huhtaniemi I, Veldhuis JD (1996) Ontogeny of pulsatile gonadotropin releasing hormone secretion from midchildhood, through puberty, to adulthood in the human male: a study using deconvolution analysis and an ultrasensitive immunofluorometric assay. J Clin Endocrinol Metab 81:1798-1805. CrossRef Medline

Xu Y, Nedungadi TP, Zhu L, Sobhani N, Irani BG, Davis KE, Zhang X, Zou F, Gent LM, Hahner LD, Khan SA, Elias CF, Elmquist JK, Clegg DJ (2011) Distinct hypothalamic neurons mediate estrogenic effects on energy homeostasis and reproduction. Cell Metab 14:453-465. CrossRef Medline

Zhang C, Bosch MA, Levine JE, Rønnekleiv OK, Kelly MJ (2007) Gonadotropin-releasing hormone neurons express KATP channels that are regulated by estrogen and responsive to glucose and metabolic inhibition. J Neurosci 27:10153-10164. CrossRef Medline

Zhang C, Kelly MJ, Rønnekleiv OK (2010) $17 \beta$-estradiol rapidly increases KATP activity in GnRH via a protein kinase signaling pathway. Endocrinology 151:4477-4484. CrossRef Medline

Zigman JM, Jones JE, Lee CE, Saper CB, Elmquist JK (2006) Expression of ghrelin receptor mRNA in the rat and the mouse brain. J Comp Neurol 494:528-548. CrossRef Medline 